\title{
Review
}

\section{Diabetes epidemiology as a tool to trigger diabetes research and care}

\section{P.Z. Zimmet}

International Diabetes Institute and Department of Biochemistry and Molecular Biology, Monash University, Melbourne, Australia

Keywords Epidemiology, Type II diabetes, epidemic, metabolic syndrome, insulin resistance, classification, criteria, leptin.

As a discipline, diabetes epidemiology is relatively young. The first significant gathering of researchers interested in diabetes epidemiology took place just in 1978 [1]. This landmark meeting, steered by the late Kelly West, set the stage for the 1979 USA National Diabetes Data Group (NDDG) [2] and subsequent 1980 World Health Organization (WHO) [3] consultations which addressed the standardization of classification and criteria for diabetes. In the relatively short span of 2 decades, epidemiology studies have had a profound impact on diabetes research, care and prevention. This review highlights some of the key contributions (Table 1).

Corresponding author: P. Zimmet M.D., International Diabetes Institute, 260 Kooyong Road, Caulfield, Victoria 3162, Australia

Based on the Inaugural Peter Bennett Epidemiology Award Lecture presented at the International Diabetes Epidemiology Group, 16th International Diabetes Federation Congress, Finland, July 1997

Abbreviations: NDDG, National Diabetes Data Group; WHO, World Health Organization; CVD, cardiovascular disease; ADA, American Diabetes Association; IFG, impaired fasting glucose; GAD, glutamic acid decarboxylase; ICA, islet cell antibody; IAA, insulin autoantibodies; IA2, tyrosine phosphatase-2; MODY, maturity-onset diabetes in the young; LADA, latent autoimmune diabetes in adults; UKPDS, United Kingdom Prospective Diabetes Study; GDM, gestational diabetes mellitus; FPG, fasting plasma glucose; 2 h-PG, 2 hour plasma glucose; DCCT, Diabetes Control and Complications Trial; DPT-1, Diabetes Prevention Trial-1; CARE, Cholesterol and Current Events Trial; CHD, coronary heart disease; INS, insulin gene; VNTR, variable number of tandem repeats; HOMA, homeostasis model assessment; PAI-1, plasminogen activator inhibitor-1; 4S, Scandinavian Simvastatin Survival Study.

\section{Diabetes - the enigmatic disorder}

Diabetes has been known for many centuries [4]. Yet, as we approach the next millennium, our knowledge of the nature of diabetes is still incomplete. This has very important implications for a rational approach to basic and clinical research, management and prevention, especially as Type II (non-insulin-dependent) diabetes mellitus is epidemic in many developing and newly industrialized nations [5].

Some of the very important developments in diabetology have emerged through epidemiology and they may not have occurred without these studies. The rising prevalence and incidence of Type II diabetes has stimulated research on the genetic, environmental, behavioural, socio-economic and cultural factors contributing to the epidemic. This highlights the sociological aspects of epidemiology and public health [6].

It would be an oversimplification to attribute all progress in diabetes research to the disciples of epidemiology. The growth of studies on the epidemiology and public health aspects was, however, necessary for the field to move forward. These studies have had a profound effect on influencing international agencies like the WHO [6] and the World Bank [7], and national governments such as those of the USA [8] and Australia [9], to address diabetes as a serious public health issue.

The explosion of interest and activity in the epidemiology of diabetes over the last 2 decades has been extraordinary. West provided a major stimulus to the upsurge by undertaking the huge task of reviewing over 2300 studies in his 1978 book "Epidemiology of Diabetes and its Vascular Lesions" [10]. West, Bennett, Keen and Jarrett were the driving forces behind the WHO Multinational Study of Vascular Disease in Diabetes [11], a world first. It was the first attempt at an international multi-centre standardized diabetes epidemiological study. This, along with the early stud- 
Table 1. The major developments in diabetes where epidemiology studies have contributed as a trigger to diabetes research

1. Providing improved understanding of the natural course of both Type I and II diabetes.

2. Providing a clearer picture of classification of diabetes leading to more rational genetic, clinical research and therapeutic approaches.

3. Charting the course and defining the magnitude of the Type II diabetes epidemic and its socio-economic and cultural components.

4. Improving diagnostic criteria for diabetes and hyperglycaemic states through a clearer delineation of the natural course of hyperglycaemia.

5. Identification of risk factors for Type II diabetes and its complications in populations around the world leading to prevention strategies.

6. Creating ability to predict future Type I diabetes and insulin dependency.

7. Providing evidence of metabolic control matters in relation to prevention of complications of diabetes.

8. Contributing to improved understanding of "when the clock starts ticking for cardiovascular disease in diabetes".

9. Exploring the controversy about the "thrifty genotype" hypothesis.

10. Describing the interrelation of hyperglycaemia, insulin resistance and other CVD risk factors: the metabolic syndrome and the putative contribution of leptin resistance.

ies in Bedford [12] and on the Pima Indians [13] was a major project that led the way in developing standardized protocols and methodologies for diabetes researchers worldwide. The WHO study showed that although arterial disease risk was consistently increased in people with diabetes in all countries studied, it reflected the overall prevalence of atherosclerosis in the background population [12]. Thus, even in a low-prevalence nation such as Japan, a person with diabetes had twice the risk of a non-diabetic person even though this risk was still only a fraction of that of a non-diabetic Europid person.

\section{The global Type II diabetes epidemic - its magnitude and projections based on epidemiological studies}

The extraordinary high prevalence of Type II diabetes reported in the Pima Indians in the late 1970 s [13] and our own finding of high prevalence in the Micronesian Nauruans in the Pacific in 1975 [14] and then later in other Pacific and Asian island populations [15] highlighted the potential for a future global epidemic. The predictions proved to be correct and Type II diabetes has now reached epidemic proportions in many developing nations and some of the Middle East Arab states [16], as well as in disadvantaged minorities in the developed countries, e.g. Australian Aboriginal and Torres Strait Islanders [17], native, African Americans and Mexican Americans [9] in the United States and migrant Asian Indians [18] and Chinese [5, 16].
Table 2. Current estimates and future projections for the number of incidents of Type I and II diabetes worldwide for the years 1997-2010 [20]

\begin{tabular}{|c|c|c|c|}
\hline $\begin{array}{l}\text { Type of } \\
\text { diabetes }\end{array}$ & 1997 & 2000 & 2010 \\
\hline $\begin{array}{l}\text { Type I } \\
\text { Type II }\end{array}$ & $\begin{array}{r}3.5 \text { million } \\
199.2 \text { million }\end{array}$ & $\begin{array}{r}4.3 \text { million } \\
147.2 \text { million }\end{array}$ & $\begin{array}{r}5.3 \text { million } \\
212.9 \text { million }\end{array}$ \\
\hline Total & 122.8 million & 151.2 million & 218.3 million \\
\hline
\end{tabular}

Over the next decade, the epidemic of Type II diabetes will continue to escalate [19]. Projections published recently [19] suggest that there will be more than 220 million people with diabetes by the year 2010 (Table 2). The majority of these will have Type II diabetes. At least 100 million people today suffer from Type II diabetes and by 2010, this will rise to 215 million. Many surveys have confirmed that increasing urbanization and industrialization is associated with an increased prevalence of Type II diabetes $[18,20]$. Inevitably, diabetes and its complications will emerge as one of the major threats to future public health resources throughout the world $[6,7,21]$.

The situation in the Indian Ocean nation of Mauritius provides a microcosm of the potential for the global diabetes epidemic. This nation, apart from having a high diabetes prevalence with a notable secular increase between 1987 and 1992 in Asian Indians and Creoles, showed the highest yet reported prevalence in Chinese [22]. This and evidence that prevalence of Type II diabetes doubled between 1984 and 1992 in Singaporean Chinese [23] and the high prevalence in Taiwan [24] provide alarming indicators of the size of the future epidemic in the People's Republic of China. Here, the overall prevalence of Type II diabetes was, until recently, less than $1 \%$ [25]. Recent studies show a threefold increase in prevalence in certain areas of China within the last 2 decades [26, 27]. The scenario is highlighted in Fig. 1 comparing the prevalence of diabetes in Chinese populations in China, Singapore, Taiwan and Mauritius. If China were to experience just one half the current rate of diabetes in Taiwan, the number of people with diabetes would increase dramatically from 8 million in 1996 to over 32 million by 2010 [19].

\section{A cardiovascular disease epidemic to follow}

Type II diabetes in these populations is the "tip of the iceberg" in a cluster of cardiovascular disease (CVD) risk factors also described as "The New World Syndrome" or metabolic syndrome [5, 18]. Very high rates of obesity, Type II diabetes, hypertension and CVD, coupled with cigarette smoking, alcohol abuse, and the other effects and outcomes of nutritional-calorific affluence, reviewed in detail elsewhere $[5,15$, 


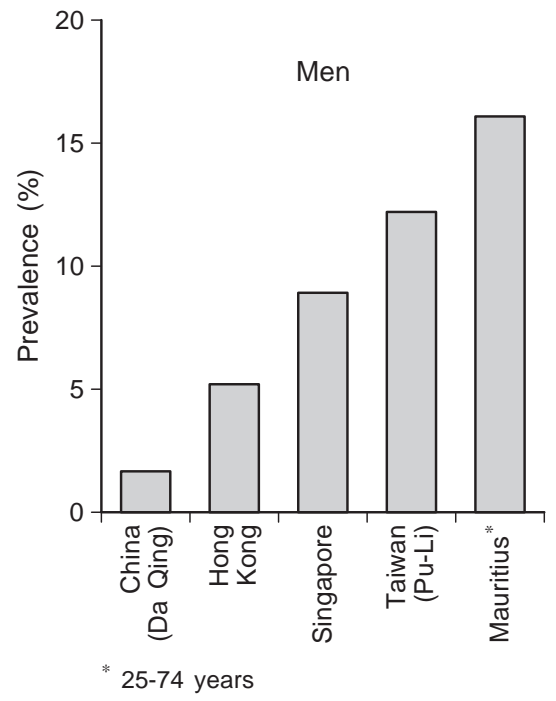

Fig.1. A comparison of the prevalence of Type II diabetes among Chinese in various countries compared with the People's Republic of China

$17,18,20]$, are just part of the modernization or "Coca-colonization" process.

The constituents of the metabolic syndrome, including Type II diabetes and its devastating macrovascular and micro-vascular complications, are imposing a high socio-economic cost and a public health burden on secondary and tertiary health care services in poor nations and in disadvantaged minorities in developed nations [8, 21]. It is usual to view Type II diabetes as a disease but, in fact, the problem that we attack as a disease is actually a symptom of a much larger global socio-economic problem $[18,21]$. Therefore, medically orientated strategies for prevention of Type II diabetes such as diet, weight loss and exercise or pharmacotherapy in isolation are likely to have a minimum impact. Prevention activities need to address social and cultural attitudes relating to behavioural change $[6,20]$. Epidemiologists have a social responsibility to continue to highlight the magnitude of the epidemic and the demographic and other risk determinants that may be amenable to modification. It is, however, a battle against the rising tide of global socio-economic forces (globalization) and resources are urgently needed to research the socioeconomic, behavioural, nutritional and public health issues.

\section{Diabetes classification - a non-stop evolution and revolution}

In the earlier part of the twentieth century, it appeared that there were many people who could be classified as having diabetes but who were generally

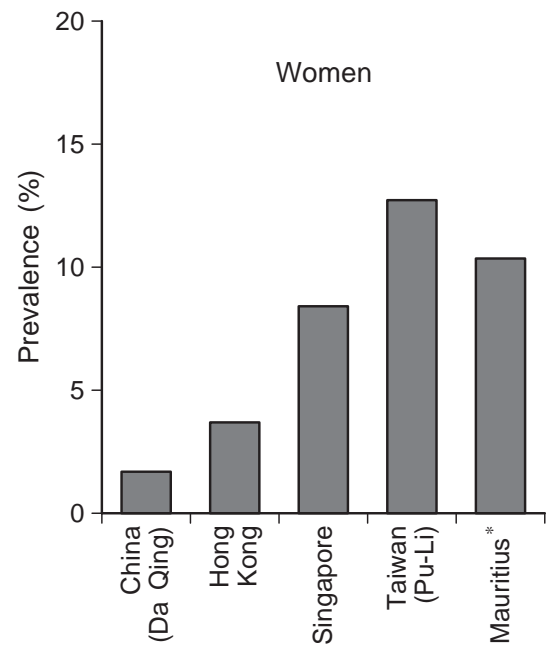

"asymptomatic". Over 60 years ago, Himsworth proposed that there were at least two clinical types of diabetes, insulin-sensitive and insulin-insensitive, and he suggested that the former was due to insulin deficiency [28]. Whereas some diabetic patients needed insulin to survive, it was clear that there was another group who did not need insulin. Himsworth's observation was based on clinical observation alone. Fifty years later, we know how true this is based on epidemiological and intensive molecular biology research. There are many potential defects that determine this, particularly for Type II diabetes [5, 29, 30].

Rationale for an orderly classification. Targeted research, treatment and prevention of both Type I (insulin-dependent) and Type II (non-insulin-dependent) diabetes mellitus depend on an appropriate, contemporary classification. Furthermore, a hallmark in understanding the aetiology of a disease, studying its natural history and investigating the genetic contribution is the ability to identify and differentiate the various forms $[5,6]$. In the past, many clinical and genetic studies in diabetes have been undertaken with inadequate and inappropriate care in relation to classification [5].

The contemporary classification of diabetes and other categories of glucose intolerance, based on scientific research on this heterogeneous syndrome, was developed 20 years ago by international work groups, the NDDG [2] and the WHO Expert Committee on Diabetes [3]. In 1985, a WHO Study Group proposed a revised classification which, although not ideal, was accepted and adopted internationally [31]. Controversy was always present with that classification [32]. It presented few problems in children but it certainly was a challenge for researchers and clinicians in the diagnosis of diabetes in adults, particularly in relation to insulin therapy $[5,33]$ and as the age of onset of Type II diabetes is now seen several decades earlier than in the past [34]. 
Table 3. Disorders of glycaemia: the aetiological types and clinical stages as recommended by the American Diabetes Association [42] and World Health Organization [43]

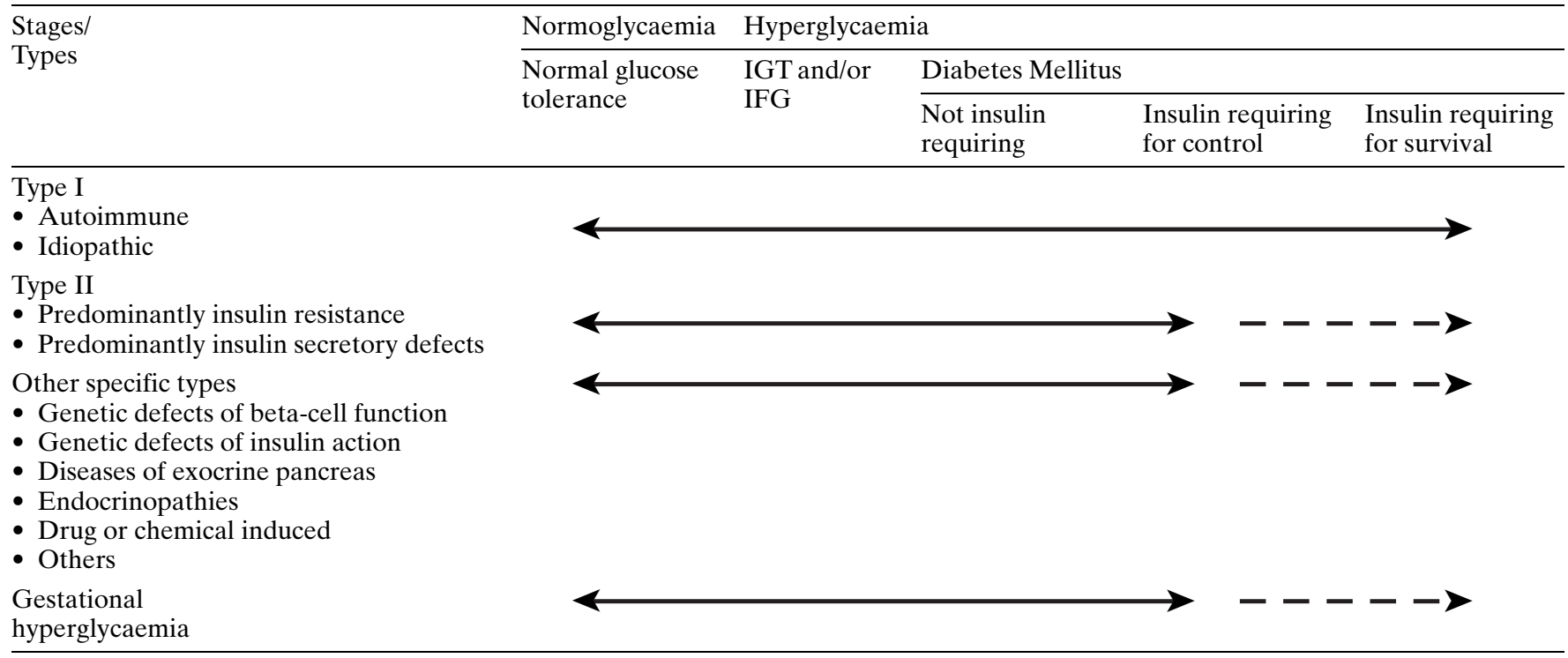

At the time, the 1985 WHO Study Group recognized that the classification would require review in the light of ongoing research as it was a compromise between a clinical and an aetiological classification [31]. That review has now taken place with the 1997 American Diabetes Association (ADA) [35] and the very recent WHO [36] report. The new classification is based on stages of glucose tolerance status with a complimentary sub-classification according to aetiological type. The concepts for this new two dimensional classification (Table 3 ) were proposed by $\mathrm{Ku}-$ zuya and Matsuda [37]. They sought to separate clearly the criteria related to aetiology and those related to the degree of hyperglycaemia and insulin requirement and to define each patient on the basis of these two criteria.

The new World Health Organization and American Diabetes Association classification. What are the changes suggested by the ADA [42], that in the main, are also recommended by the WHO [43]? The new classification finds strength in that it is supported by numerous epidemiological studies cited in these reports. The classification by aetiological type results from new knowledge of the causes of hyperglycaemia including diabetes $[29,32]$. The actual staging (Table 3 ) reflects that any aetiological type of diabetes can pass or progress through several clinical phases (both asymptomatic and symptomatic) during its natural course and patients can move in either direction, from stage to stage.

The newly proposed staging. Hyperglycaemia, regardless of the underlying cause, is subcategorized into:
1. Normoglycaemia.

2. Impaired glucose tolerance (IGT) and impaired fasting glucose (IFG): IGT is now categorised as a stage in the natural course of disordered carbohydrate metabolism. A stage designated IFG is now recognised.

3. Insulin requiring for survival (former category Type I diabetes).

4. Insulin requiring for control (those requiring insulin for metabolic control rather than for survival) and 5. Not insulin requiring (may be treated by non-pharmacological methods or drugs other than insulin).

The latter two categories correspond to what was formerly non-insulin-dependent diabetes mellitus (NIDDM). Almost all subjects can be categorised according to clinical stage although aetiological categorization may not always be possible in some circumstances, e.g. where the measurement of autoantibodies and other adjunctive tests such as $\mathrm{C}$ peptide are not available.

Aetiological types. The aetiological types listed represent processes which may result in diabetes. Type I indicates the process of beta-cell destruction that may ultimately lead to diabetes in which "insulin is required for survival" to prevent ketoacidosis, coma and death. The Type I process is characterised by the presence of autoantibodies to glutamic acid decarboxylase (GAD), islet cell (ICA), insulin (IAA) or tyrosine phosphatase-2 (IA2) which identify the autoimmune process associated with beta-cell destruction [39]. In some cases, no evidence of antibodies is, however, present and these are classified as "Type I idiopathic". 
Type II is the commonest form of diabetes and is characterised by disorders of insulin resistance and insulin secretion, either of which can be the predominant feature. Both are usually present at the time that the diabetes is clinically manifest [38]. Patients, formerly categorized as having Type II diabetes in which the defect is now known, e. g. in maturity-onset diabetes in the young (MODY) [39], now appear under "other specific types". The other specific types are less common but are those in which the underlying defect or disease process can be identified in a relatively specific manner, particularly those where a monogenic defect has been identified as in MODY [39].

The classification - challenges for medical science and society. Diabetes provides an excellent example of how diagnosis based on relatively "soft" criteria, certainly still lacking the standards set for evidencebased medicine, can have an important impact on the individual and society. Here, epidemiologists have a responsibility for health-care research to provide information leading to decisions that can affect the every day life of the diabetic person, including societal, legal, employment and insurance aspects [21, 31]. The following section describes epidemiological and clinical studies which have helped to unravel classification issues as it pertains to Type I diabetes, particularly in adults.

Anti-GAD studies - classifying diabetes in adults. Type I diabetes occurs at all ages [33, 40]. Some $44 \%$ of all new cases of Type I diabetes in Denmark are diagnosed after 30 years of age [41]. The clinical presentation can vary with age $[35,36]$ and it generally has a typical clinical and biochemical presentation, especially in children. Failure to treat immediately with insulin can be life-threatening. In adults, Type I diabetes can, however, masquerade as Type II diabetes at presentation with a slow deterioration in metabolic control and later progress to insulin-dependency $[5,40]$. The classification of diabetes in adults therefore poses a challenge and this issue has been reviewed in detail elsewhere $[5,33,40]$. Our interest in this relates to the question of autoimmune diabetes in adults that presents clinically as Type II diabetes and the prediction of future insulin dependency. We have designated this as latent autoimmune diabetes in adults (LADA) [40]. In the new classification, LADA falls within Type I autoimmune diabetes but in a slowly progressive form [36]. The diagnosis of LADA becomes even more of a challenge given that the age of onset of Type II diabetes appears to have moved several decades to younger age groups and is not uncommon in the 25 to 35 year age group, particularly in high prevalence populations [34].

Our early studies using the anti-GAD assay to describe LADA were not population-based but clinicbased $[40,42]$. To have any credibility and applicabil- ity, particularly for future prediction of Type I diabetes or insulin dependency or both, estimates of LADA prevalence required an epidemiological perspective. The opportunity for this came through the cohort of the Finnish Women's Study [43] and with the United Kingdom Prospective Diabetes Study (UKPDS) cohort, a randomized clinical trial [44]. What did these studies show that helped with screening and clinical practice relating to the risk of future Type I diabetes and the prediction of insulin dependency in adults with diabetes?

In 1991, I became interested in the concept that a practical assay for anti-GAD might have a useful role in the discrimination of adult subjects where there was doubt as to whether they had Type II diabetes or a slow-onset Type I diabetes, now designated as LADA. This latter form of diabetes had been described previously and the presence of ICA positivity shown [45, 46]. The lack of accessibility for most clinicians to the ICA immuno-fluorescent assay even in developed countries, along with the technical difficulties, made it, however, totally unsuitable for widespread use for classification. We suggested that testing for anti-GAD in adult-onset, particularly nonobese, diabetic patients might eventually become routine for predicting future insulin-dependency at a much earlier stage for initiating more appropriate therapy and that the test could assist in the correct classification of diabetes [5, 42].

There was considerable resistance to this idea from researchers in the ICA field as ICA was considered to be the "gold standard". The evidence has, however, mounted from a host of studies that antiGAD has a clear role in diagnosing slow-onset Type I diabetes in adults [40, 42, 43, 47-51] and, indeed, in predicting future insulin dependency [33, 50-52]. Other workers have recommended, as we have [53], that all women with gestational diabetes mellitus (GDM) should have an anti-GAD test [54]. Only the widespread lack of inexpensive commercial antiGAD assays has hindered the more general use in clinical practice for classification of diabetes in adults but this is likely to change as the assay becomes more widely available.

We have tested the above recommendations in several studies including the landmark United Kingdom Prospective Diabetes Study (UKPDS) of Type II diabetes [52]. One of the most convincing arguments for the importance of LADA comes from this study. Islet cell antibodies and anti-GAD were measured at diagnosis in 3672 patients selected by family physicians as having "typical" Type II diabetes [52]. Of these patients, the overall proportion with ICA was $5.8 \%$ and anti-GAD $9.8 \% ; 12 \%$ of patients had either ICA or anti-GAD and $3.9 \%$ had both (Table 4). These subjects clearly have Type I diabetes or LADA as judged by both phenotypic [52] and genotypic [55] features. The presence of autoantibodies 
Table 4. Prevalence of antibodies to glutamic acid decarboxylase (anti-GAD) and of ICA in 3672 newly diagnosed Type II diabetic patients from the UKPDS (adapted from ref.61)

\begin{tabular}{lll}
\hline Autoantibody & No. & $\%$ \\
\hline ICA positive $^{\mathrm{a}}$ & 213 & 5.8 \\
Anti-GAD positive $^{\mathrm{b}}$ & 361 & 9.8 \\
Both positive & 141 & 3.9 \\
\hline
\end{tabular}

${ }^{a}$ ICA positive: 5 Juvenile Diabetes Foundation units or more

${ }^{\mathrm{b}}$ Anti-GAD positive: more than 20 units

correlated particularly with a younger age and phenotypic features consistent with Type I diabetes including early age at diagnosis, lower body mass index (BMI) and reduced beta-cell function (Table 5) [52]. Overall, of the proportion requiring insulin by 6 years, $38 \%$ were anti-GAD positive at baseline. Only $5.3 \%$ of those not on insulin at 6 years were anti-GAD positive at baseline (Table 5).

At all ages, the presence of autoantibodies conferred an increased likelihood of decompensation to insulin therapy [52]. Thus $94 \%$ of patients aged under 35 years positive for ICA and $84 \%$ of those positive for anti-GAD at baseline required insulin therapy after 6 years compared with $14 \%$ of sero-negative patients. In addition, a recent study in Sweden found that autoimmune markers were present in $10 \%$ of incident diabetes in people aged 40-75 years [51]. This result is entirely consistent with the UKPDS antiGAD findings.

The Tasmanian Insulin-Treated Diabetes Register consists of patients with Type I and Type II diabetes receiving insulin [56]. We investigated the association of anti-GAD positivity with early commencement of insulin treatment in adult-onset diabetes to ascertain whether this association is stronger than other phenotypic characteristics often used for classification of diabetes [57]. In this cohort, $36 \%$ of males and $39 \%$ of females were found to be positive for anti-GAD. For males, factors associated with early insulin treatment included anti-GAD positivity, a family history of diabetes and a lower BMI at diagnosis [57]. For females, the factors associated with early insulin treatment included anti-GAD positivity and absence of obesity. Age at diagnosis was not associated with either male or female subjects. In multi-variate models, anti-GAD positive status was the only variable associated with early insulin treatment for both sexes. Scatter-plots of age at diagnosis by time from diagnosis to insulin therapy initiation showed anti-GAD negative subjects had a large degree of variation in the period from diagnosis to insulin treatment (Fig. 2). Most anti-GAD positive subjects commenced insulin treatment soon after diagnosis.

Perhaps the next important question was whether measurement of IAA and antibodies to IA 2 provided any additional diagnostic or predictive value for Type I diabetes. Both IAA [58] and anti-IA2 [59] have relatively low prevalence in adults and appear to add very little to diagnosis. Using the Finnish women cohort [42] to study presymptomatic auto-antibody markers of Type I diabetes, we measured anti-GAD, anti-IA2 and ICA and compared frequencies and levels in 139 women from whom serum had been archived during antecedent pregnancies for 10 years [60]. Of the 35 women sero-positive for one or more autoantibodies, $77 \%$ developed Type I diabetes, $11 \%$ Type II diabetes, 9\% GDM requiring insulin and $3 \%$ GDM-diet (Table 6). The frequency of antibodies during the 10 year pre-diagnosis period is shown in Table 6 and was $83 \%$ for anti-GAD, $52 \%$ for anti-IA2 and $41 \%$ for ICA for those women who developed Type I diabetes, $25 \% ; 17 \%$ and $0 \%$, respectively for Type II diabetes; $12 \%, 4 \%$ and $8 \%$, respectively for GDM requiring insulin and $1 \%, 0 \%$ and $1 \%$, respectively for GDM-diet.

This study highlighted the long latency of seropositivity before overt Type I diabetes in women, the predominance of anti-GAD among these three serological markers, and the presence of these markers in women with Type II diabetes, possibly suggesting that the latter were likely to have autoimmune insulitis but this masqueraded as Type II diabetes in their initial presentation.

Table 5. Mean characteristics of patients at diagnosis and outcome of therapy in 1870 patients who were not randomly assigned to insulin from the UKPDS (adapted from ref. 61)

\begin{tabular}{|c|c|c|c|c|}
\hline \multirow[t]{2}{*}{ Characteristics of patient } & \multirow{2}{*}{$\begin{array}{l}\text { All } \\
(n=3672)\end{array}$} & \multicolumn{2}{|l|}{6 Year outcome } & \multirow[t]{2}{*}{$p$} \\
\hline & & $\begin{array}{l}\text { Not Requiring Insulin } \\
(n=1633)\end{array}$ & $\begin{array}{l}\text { Requiring Insulin } \\
(n=237)\end{array}$ & \\
\hline BMI $\left(\mathrm{kg} / \mathrm{m}^{2}\right)^{\mathrm{a}}$ & 29.3 & 29.5 & 27.6 & $<0.0001$ \\
\hline beta-cell function $(\% \beta)^{\mathrm{b}}$ & 36 & 41 & 26 & $<0.0001$ \\
\hline ICA positive (\%) & $5.8 \%$ & $48(2.9 \%)$ & $62(26.2 \%)$ & $<0.0001$ \\
\hline Anti-GAD positive (\%) & $9.8 \%$ & $87(5.3 \%)$ & $90(38 \%)$ & $<0.0001$ \\
\hline
\end{tabular}

Data are mean $(\mathrm{SD})^{\mathrm{a}}$, median $(\mathrm{IQR})^{\mathrm{b}}$ or number $(\%)$ of patients

Beta-cell function was defined by the homeostasis model assessment (HOMA) model 


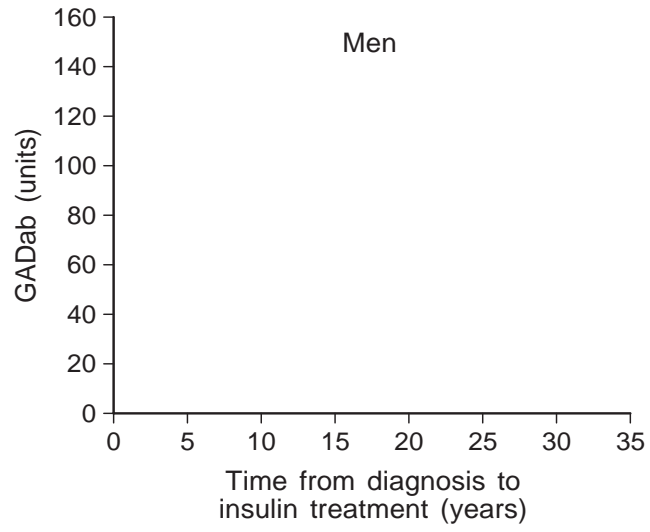

Fig. 2. Relation of age at diagnosis, BMI at diagnosis and antiGAD to time from diagnosis to start of insulin treatment for men and women from the Tasmanian Insulin Treated Register (anti-GAD $>20$ is positive) (adapted from ref. 66)

\section{"Pollution" of genetic and clinical research studies in diabetes}

A major outcome of recent studies on anti-GAD and other markers of autoimmunity, highlighting the poor classification of diabetes in adults, is that many genetic and clinical research studies, as well as pharmaceutical trials of new oral hypoglycaemics and insulin for treatment of Type II diabetes have been "polluted" by subjects with LADA and MODY subjects [5, 33]. There are also equally important implications for the correct classification of subjects for the trials of prevention of Type II diabetes now underway [61]. It should be mandatory to screen all participants with anti-GAD and other autoantibodies in future Type II diabetes studies. This applies particularly to genetic studies as discussed below.

Diabetes classification and molecular biology. Molecular genetic research directed at linking Type II diabetes susceptibility to putative gene/s has a vital role in determining "high risk" people, a group for targeted primary prevention activities [5]. A high priority

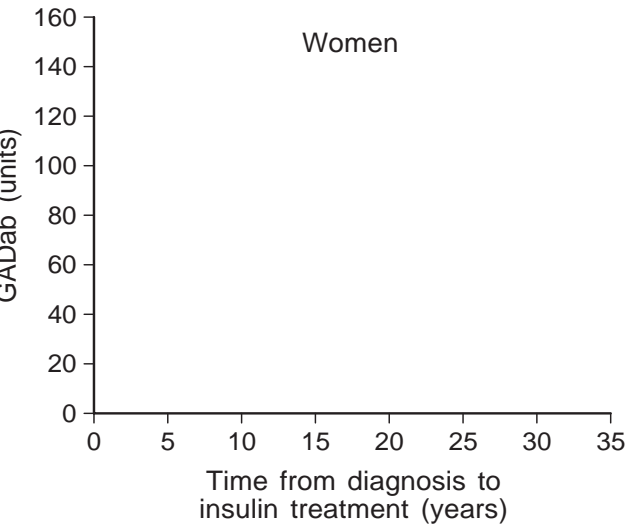

was a scientifically based classification of the diabetes syndrome as the means for separating Type I and II diabetes. A starting point for this is the classification now proposed by the ADA [35] and WHO [36]. These reports are a testament as to how epidemiological studies have aided diabetes research, care and prevention.

Although it will require fine tuning in the future, the new classification $[35,36]$ should bring a more rational approach to research by molecular biologists, clinicians and public health workers alike. Apart from the necessity to define diabetes correctly from an epidemiological and therapeutic perspective, the total success of the current thrust to define crucial genes for both Type I and II diabetes depends on this. It is not surprising that most geneticists still regard diabetes as the "geneticists' nightmare" when clinicians have been asking them to find the diabetes gene/s while providing samples from poorly defined groups. Until recently they have been given biological samples and inadequate phenotypic data from patients who were said to be representative of either Type I or Type II diabetes [5].

The search for the Type II diabetes gene/s is difficult enough without this additional handicap. The recent important breakthroughs in the genetics of diabetes have come from studying very well-defined autosomal dominant forms in extended families with MODY [29, 30, 39] and not from the vast and clearly heterogenous pool of people with Type II diabetes

Table 6. Women with a positive test for anti-GAD, anti-ICA512, and ICA during a 10-year presymptomatic period before the diagnosis of diabetes in a cohort of 139 Finnish women from whom multiple samples were assayed (adapted from ref. 69)

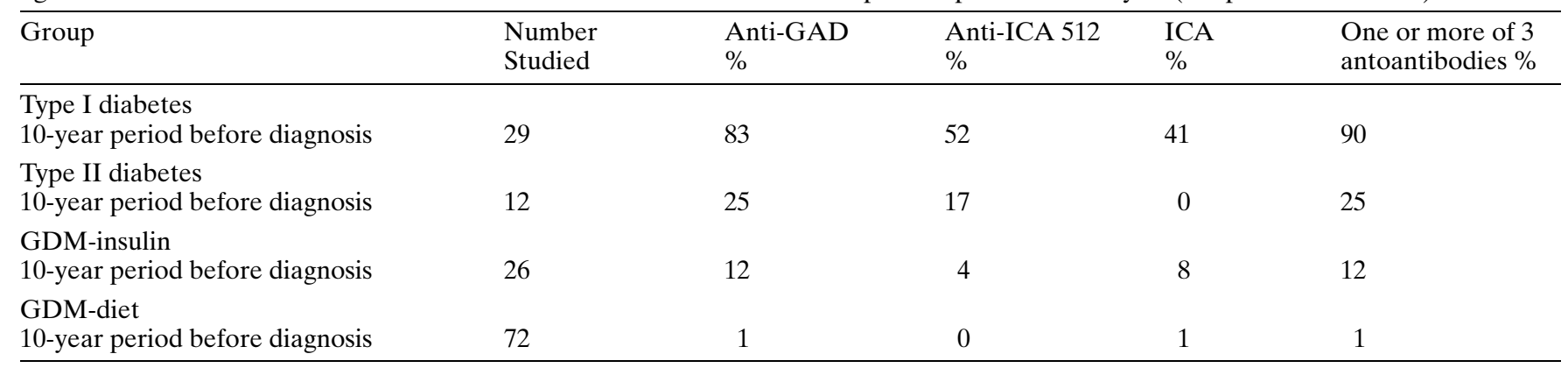


with or without the other components of the metabolic syndrome [38]. Recent years have seen some very exciting developments in mapping the genes for MODY [39]. This is a familial condition with autosomal dominant inheritance and it has been shown that the disorder is frequently linked to the glucokinase gene on chromosome 7 [62] and to the region of the adenosine deaminase gene on chromosome 20 [63]. In late 1996, Bell and his colleagues reported the identification of a further two genes associated with MODY. In a form known as the gene MODY 3, the gene encodes for hepatocyte nuclear factor-1 $\alpha$ [64]. In MODY 1, they found mutations in the hepatocyte nuclear factor- $4 \alpha$ gene on chromosome 20 . This is placed in the region of the adenosine deaminase gene where their earlier studies [63] had found a linkage. More recently, mutations in the insulin receptor substrate (IRS) gene have been found to be associated with some MODY families [46].

Although MODY only accounts for about $1 \%$ of all Type II diabetes, the implications for discovering other genes for other forms of diabetes are both profound and exciting. Yet, to find gene/s associated with any complex disorder such as diabetes, the task is more formidable. The failure to find a major putative gene for Type II diabetes despite the advanced stage of the Human Genome Project [66] raises many questions as to what is the most appropriate strategy. Finding the gene/s has enormous implications not only for screening for high-risk people but for targets for potential new therapeutic compounds. Epidemiologists must continue to have a pivotal role in helping to define the best cohorts for these genetic studies.

\section{New diagnostic criteria for glucose intolerance}

International debate continues as how best to define criteria for glucose intolerance $[32,67,68]$. The current recommendations for its diagnosis are at best a compromise agreed between authorities who have reviewed the epidemiological literature and its data bases for a "best fit" situation. The changes in diagnostic criteria are discussed in detail in the ADA [35] and WHO [36] reports. The recommendations have been arrived at, in the main, on the basis of cross-sectional and prospective epidemiological studies. The most substantive change is the lowering of the fasting plasma glucose (FPG) concentration for the diagnosis of diabetes from $7.8 \mathrm{mmol} / \mathrm{l}(140 \mathrm{mg} /$ dl) to $7.0 \mathrm{mmol} / \mathrm{l}(126 \mathrm{mg} / \mathrm{dl})$. The new category of IFG of 6.1 to $7.0 \mathrm{mmol} / \mathrm{l}(111 \mathrm{mg} / \mathrm{dl}$ to $126 \mathrm{mg} / \mathrm{dl})$ has been created. In addition, the ADA recommended virtual abolition of the oral glucose tolerance test (OGTT) [35]. The WHO report [36] has not, however, gone so far as to agree with this latter recommendation.
As diabetes can usually be diagnosed without an OGTT, this test is not often used to diagnose diabetes in a clinical setting. It has been mainly used for clinical research and epidemiological studies. This is not, however, the case for IGT as it requires an OGTT for diagnosis [31]. Whereas in many settings, the logistics and costs of measuring glycated haemoglobin are less than those of obtaining fasting blood or doing an OGTT, the current disadvantage of glycated haemoglobin is the lack of standardization of methodology as well as a universal reference standard for interlaboratory calibration [35]. In addition, there are fewer evidence-based outcome data available than for the OGTT. It is possible that these limitations will be overcome [36].

Although several arguments exist for abolishing the OGTT as a routine screening test for Type II diabetes $[35,67]$ and there is considerable retest variability in the OGTT, a major argument for retaining it is the identification of IGT subjects for trials of Type II diabetes prevention and for screening and the diagnosis of GDM. In addition, the 2-hour plasma glucose (2h-PG) value from the OGTT was in particular recommended by WHO for epidemiological studies to overcome uncertainties about whether study subjects were fasting or not [31].

The blood glucose concentration is a continuum, and therefore the choice of a distinct cut-point will always appear to be somewhat arbitrary and controversial. The determination of diagnostic cut-points which gave rise to the earlier NDDG [2] and WHO [31] recommendations were based on studies which showed bimodality of both fasting and $2 \mathrm{~h}$ PG in the Pima Indians [69] and Nauruans [70] (Fig. 3). The diagnostic cut-point of $11.1 \mathrm{mmol} / \mathrm{l}$ $(200 \mathrm{mg} / \mathrm{dl})$ for the $2 \mathrm{~h}-\mathrm{PG}$ concentration was originally adopted as the bimodality in Pima Indians [69] and Nauruans [70]. It suggested that a plasma glucose concentration of approximately $11.1 \mathrm{mmol} / \mathrm{l}$ best represented the point separating the two components of the frequency distribution. In addition, when the prevalence of microvascular complications, i.e. retinopathy and proteinuria was plotted against the $2 \mathrm{~h}-\mathrm{PG}$ value, it sharply increased at about $11.1 \mathrm{mmol} / \mathrm{l}$ [71].

Using the WHO criteria [31] to define Type II diabetes, it became apparent that FPG and $2 \mathrm{~h}-\mathrm{PG}$ detect different sectors of the hyperglycaemic state. This was clear almost a decade ago from a study from 13 Pacific countries [70]. The WHO FPG criterion for diabetes $(7.8 \mathrm{mmol} / \mathrm{l}$ or $140 \mathrm{mg} / \mathrm{dl})$ represents a greater degree of hyperglycaemia than the $2 \mathrm{~h}-\mathrm{PG}$ criterion for diabetes $(11.1 \mathrm{mmol} / \mathrm{l}$ or $200 \mathrm{mg} / \mathrm{dl})$ (Fig.4), and an FPG of $7 \mathrm{mmol} / \mathrm{l}(120 \mathrm{mg} / \mathrm{dl})$ provided closer parity (Fig. 5).

As discussed earlier, an important reason for continuing with the OGTT could be the identification of subjects with IGT for trials of Type II diabetes pre- 

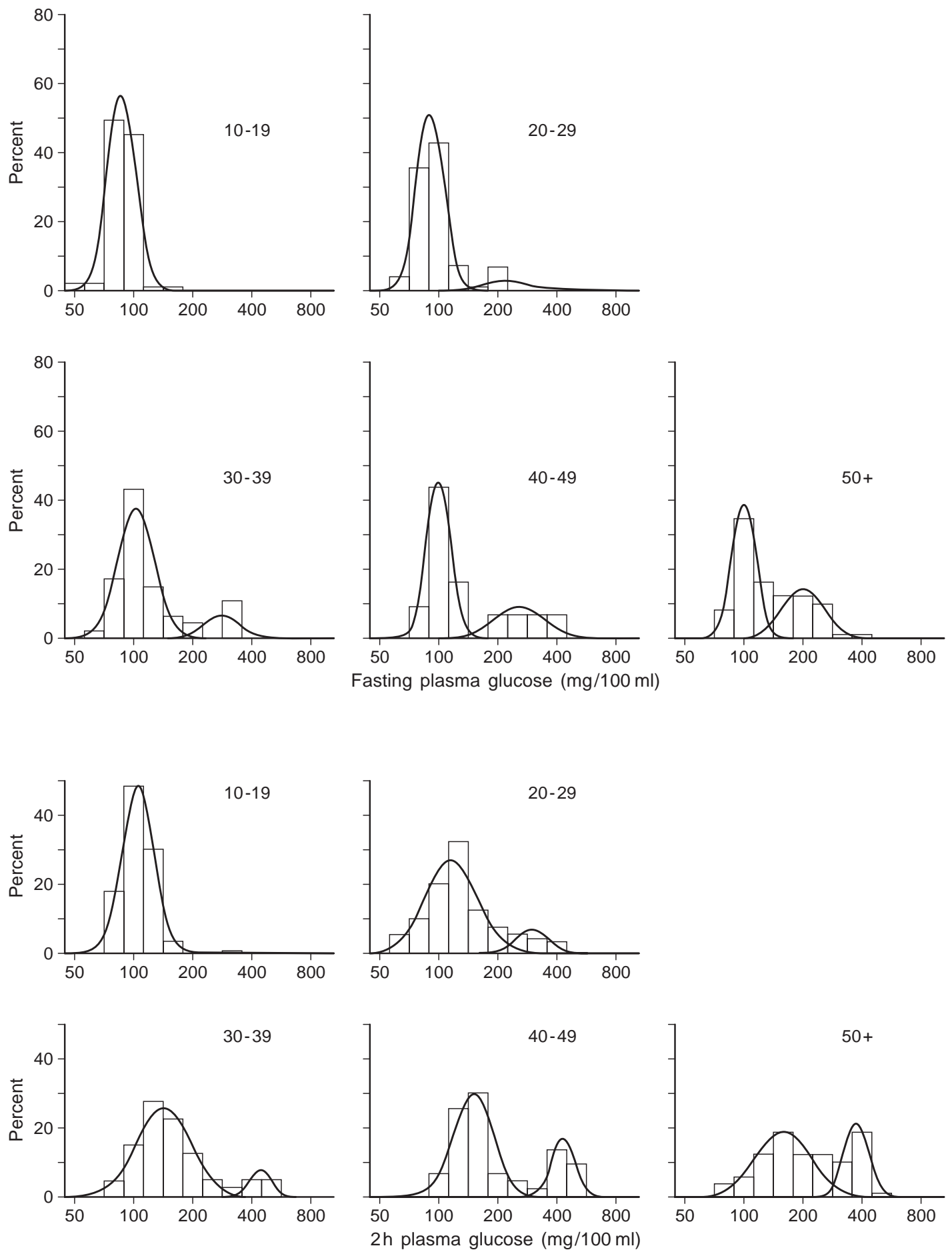

Fig. 3. Frequency distributions of fasting and 2-h plasma glucose (oral glucose tolerance test) for Nauruan females by decade (from ref. 80 )

vention. A major problem in the United States seems likely if the OGTT is dropped. The rationale for retaining it is to identify high-risk subjects, i.e. people with IGT for trials of prevention and for identifying people who should be treated if the trials on IGT are positive. The potential efficacy of non-pharmacologic and pharmacological measures for preventing Type II diabetes has been given a high priority by the national institutes of health in the United States as they funded the Diabetes Prevention Program 2 (DPP-2) [59], a multi-centre IGT intervention. Substantial outcome data exist worldwide for IGT in terms of risk of future Type II diabetes but few for IFG. Nevertheless, arguments remain for abolishing the OGTT as a routine screening test for Type II diabetes $[35,65]$. 


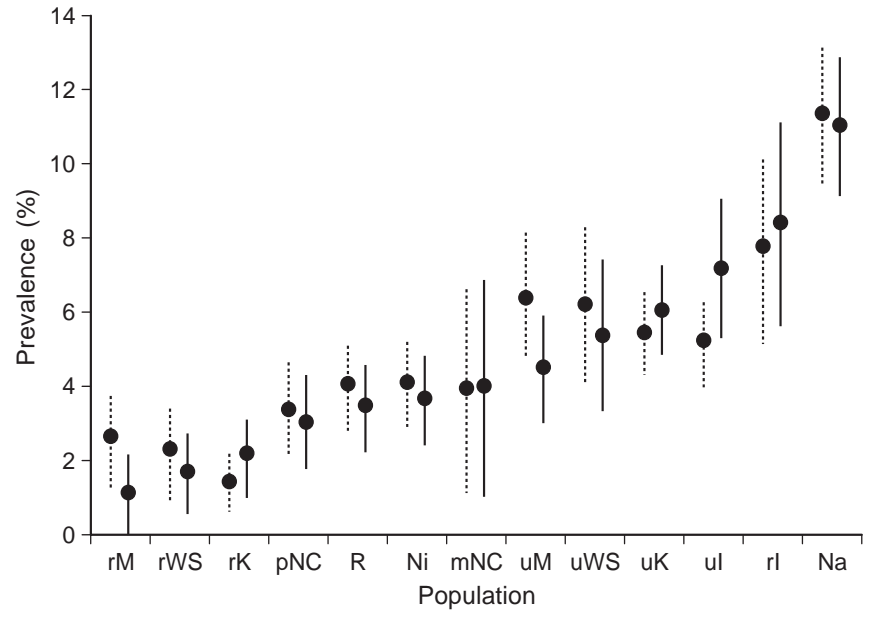

Fig.4. Comparison of prevalence estimates for diabetes using a fasting plasma glucose cut-off of $7 \mathrm{mmol} / \mathrm{l}(126 \mathrm{mg} / \mathrm{dl})$ $(\cdots \circ \cdots)$ with the prevalence defined by a 2 -h post-glucose load value of $11.1 \mathrm{mmol} / \mathrm{l}(200 \mathrm{mg} / \mathrm{dl})(--)$ in 13 Pacific populations (from ref. 82)

Abbreviations for the populations: R-Raratonga; Ni-Niue; uKurban Kiribati; rK-rural Kiribati; ul-urban Fiji Indian; rl-rural Fiji Indian; uM-urban Fiji Melanesian; rM-rural Fiji Melanesian; mNC-New Caledonian Melanesian; pNC - New Caledonian Polynesian; Na-Nauru; uWS-urban Western Samoa; rWS-rural Western Samoa

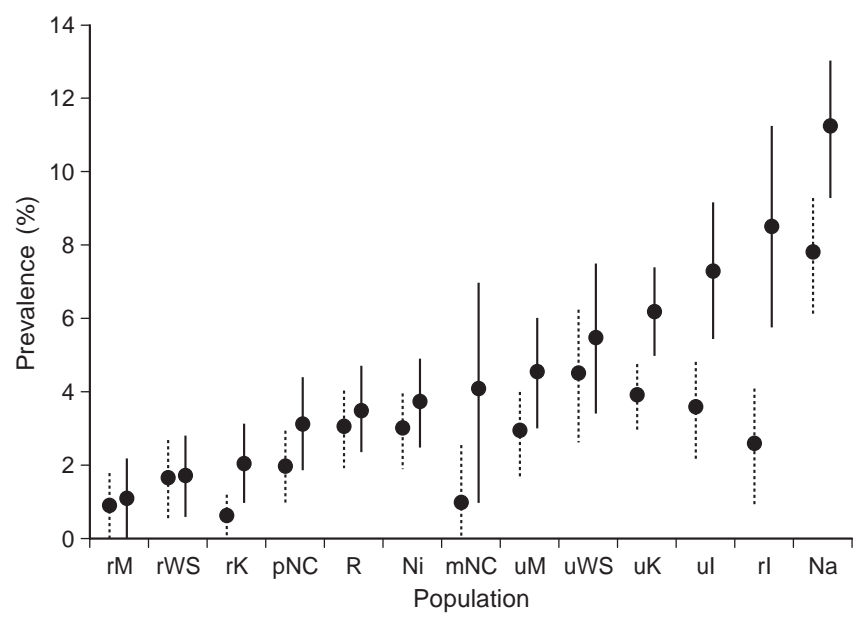

Fig.5. Comparison of prevalence estimates for diabetes using a fasting plasma glucose cut-off of $7.8 \mathrm{mmol} / \mathrm{l}(140 \mathrm{mg} / \mathrm{dl})$ (- - - -) with the prevalence defined by a 2 -h post-glucose load value of $11.1 \mathrm{mmol} / \mathrm{l}(200 \mathrm{mg} / \mathrm{dl})(\longrightarrow-)$ in 13 Pacific populations (from ref. 82)

Finally, IFG has been introduced as a result of evidence that an FPG below $7.0 \mathrm{mmol} / \mathrm{l}$, the diagnostic threshold for diabetes, may not be normal as it is associated with risk factors for both macrovascular disease and future diabetes. The Paris Prospective Study reported that the risk of developing diabetes over 3 years was greater amongst middle-aged men with an FPG greater than $6.1 \mathrm{mmol} / \mathrm{l}$ than for those with a lower FPG [71]. Within the same cohort, it has also been reported that CHD mortality is raised amongst subjects with FPG 5.8 to $6.9 \mathrm{mmol} / \mathrm{l}$ [72]. Although IFG may be analogous to IGT, it is not the same. Fewer than $50 \%$ of people with IFG also have IGT, with a substantial proportion having a $2 \mathrm{~h}-\mathrm{PG}$ in the diabetic range [73-75] (but this would not be detected if an OGTT is not done). Furthermore, IFG detects fewer of the people who subsequently progress to diabetes than does IGT [76].

\section{Screening for diabetes}

Screening for Type II diabetes. Major ethical issues arise as to whether there are sufficient reasons for screening for diabetes given the state of play in prevention of Type II diabetes [65, 76]. There has been a protracted and controversial debate on this point and it is summarized in detail elsewhere $[65,76,77]$. What is not disputed is that the chronic hyperglycaemia of diabetes is associated with long-term damage and dysfunction of various organs, especially the retina, kidney, nerves and cardiovascular system $[35,76$, 77].

Type II diabetes places a huge burden on populations both in terms of suffering and costs $[6,7,21$, 79]. In addition, there is a worldwide rise in Type II diabetes prevalence and this form of diabetes is a prime target for prevention [5, 18]. Arguments for screening for Type II diabetes also come from epidemiological studies in Europids showing that approximately half of the people with Type II diabetes are not aware of their condition and in Pacific and Asian populations, often there are more than four unknown incidences for each known one [15]. Hyperglycaemia can be present for many years before the diagnosis is made [80]. A review of a number of population-based epidemiological studies of diabetic retinopathy has shown that at diagnosis of Type II diabetes up to $20 \%$ of patients already have early diabetic retinopathy, so microvascular changes precede overt symptoms in many patients [81]. In addition, many of these subjects have other CVD risk factors [80]. Furthermore, subjects with IGT are at substantially higher risk of developing Type II diabetes [20] and are more likely to develop CVD [20, 82]. Thus, early detection by screening could provide an opportunity to reduce the progression of both microvascular and macrovascular disease due to asymptomatic hyperglycaemia.

Epidemiological studies show that the degree of hyperglycaemia and its duration are closely associated with microvascular (retinopathy and nephropathy) and neuropathic complications of diabetes [6, 11, 15, 83-85]. Along with this, evidence that infants born to diabetic women have an increased risk of fetal malformation, prematurity, spontaneous abortion, macrosomia and metabolic abnormalities adds fur- 
ther support for early detection of diabetes to reduce the risk of complications [86]. Although not a classic epidemiological study, the case-control design of the Diabetes Control and Complications Trial (DCCT) [87] has had an enormous influence on recent trends in diabetes management and is discussed later.

Screening for Type I diabetes. Prevention of Type I diabetes is an important contemporary topic with a number of major studies, e.g. the Diabetes Prevention Trial-1 (DPT-1) in the United States [88] and the European Nicotinamide Diabetes Intervention Trial (ENDIT) [89] currently in progress to test both primary and post-primary interventions, respectively. Current strategies include nicotinamide, cyclosporin and other immunosuppressive agents although the side effects of the latter two agents make them unsuitable for routine use. More recently, there has been great interest in inducing tolerance using oral and parenteral insulin $[88,90]$ as well as oral GAD which has been successful in preventing autoimmune disease in non-obese diabetic (NOD) mice [91]. The use of oral insulin is currently being explored in DPT-1 [88]. As GAD65 can be produced in large amounts through recombinant gene technology, it should soon be possible to test whether treating humans with oral GAD can halt the autoimmune process, and indeed, progression to overt clinical Type I diabetes.

With the increasing availability of tests for ICA, IAA, anti-GAD and anti-IA2, the tools exist to predict Type I diabetes with a reasonable degree of certainty [33,56-58, 92]. A major ethical issue arises as Type I diabetes cannot currently be prevented in high-risk subjects [93]. Is it reasonable to test for autoantibodies in at-risk subjects or, indeed, all schoolchildren? The current opinion is that such testing should not be done routinely but only as part of a carefully managed research programme where appropriate counselling is available to the family participants.

It may be a different scenario for LADA. This slow-onset form of Type I diabetes can be identified using the anti-GAD assay as a high proportion (70 to $80 \%$ ) are likely to be positive [40, 50-52]. Their identification could lead to the earlier institution of insulin therapy, with preservation of residual beta-cell function [94]. This, in turn, may permit better metabolic control of diabetes, so possibly reducing the risk of long-term microvascular complications of diabetes [94]. Therefore, in this situation, use of the anti-GAD assay could be both health and cost effective. Similarly, the identification of a subgroup of patients with GDM who are positive for anti-GAD has the same implications [53, 54]. These women would be the subset most likely to develop Type I diabetes at a later time [54]. In addition, they are probably the group most likely to require and benefit from insulin therapy during pregnancy.

Since autoantibodies to GAD, insulin and IA2 occur in presymptomatic Type I diabetes with differences in frequencies according to age and sex [58-60, 92], their interpretation in terms of risk of development of diabetes requires further study. Anti-GAD is seen with highest frequency in older subjects whereas the reverse is true for IAA and anti-IA2 $[58,92]$. It is possible that the stimuli to autoimmunity operate differently at various ages and according to sex $[58,59]$. The reported differences in HLA alleles [95] and auto-antibody profiles in early-onset and late-onset Type I diabetes could reflect HLA-dependent differences in antigen presentation to T-cells at different ages from infancy to adult life. This provides a challenge to epidemiologists and other researchers to further examine Type I diabetes for heterogeneity in aetiology.

There is now a burst of intervention studies for Type I diabetes and these have recently been reviewed [93]. Some are likely to lack the statistical power for a meaningful outcome. Studies based around a well-developed population-based cohort of Type I diabetic subjects and relatives are much more likely to be beneficial to scientific knowledge. Researchers embarking on preventive studies have a responsibility to consult and plan them with epidemiologists and biostatisticians to ensure both representative and large enough samples to show statistical predictive power for the intervention.

\section{Evidence that metabolic control matters}

Numerous epidemiological studies have shown the importance of indices of glycaemic control and the duration of diabetes in determining the prevalence and incidence of diabetic microvascular complications $[10,15,85,96]$. Pirart's large prospective study on diabetes and its complications in 4400 patients observed between 1947 and 1973 suggested that metabolic control mattered [97]. Subsequent epidemiological data supported that concept but it required testing in large scale clinical trials. The opportunity to do this was provided by the Diabetes Control and Complications Trial [87] and the Stockholm Study [98] both of which showed that improved glycaemic control reduces the risk of microvascular complications in Type I diabetes. These findings applied to patients with Type I diabetes but large trials such as the UKPDS [44] confirmed they could be extrapolated to patients with Type II diabetes. The Kumamoto study on intensive therapy for Type II diabetes [99] produced similar results as the DCCT. It used a protocol almost identical to that of the DCCT and similar benefits were noted with a 50 to $75 \%$ reduction in complications. The recently published findings of the 
UKPDS [100, 101] now provide strong evidence to recommend tight glycaemic control in Type II diabetes. These results strongly suggest that the lesson that metabolic control matters, as shown by the DCCT and the Stockholm study, does have relevance to Type II diabetes. Although neither the UKPDS nor the DCCT could strictly be designated as classical epidemiological studies, their magnitude, design and high standards of investigation permit referencing here as examples of the contribution from epidemiology.

\section{Type II diabetes and vascular disease}

Two-thirds of Type II diabetic patients die from cardiovascular disease [102]. The clustering of Type II diabetes, a well-documented risk determinant for CVD, with the other risk factors, including insulin resistance, that constitute the metabolic syndrome is now well established [103, 104]. This seems the most likely explanation for this increased CVD mortality in Type II diabetes. Alone, each component of the cluster conveys increased CVD risk but, as a combination, their effect is cumulative.

Important and pivotal studies relevant to this CVD risk were the randomized clinical trials of cardiovascular interventions, the Scandinavian Simvastatin Survival Study (4S) [105] and Cholesterol and Current Events Trial (CARE) [106]. The use of simvastatin in diabetic subjects with a previous CHD event resulted in a $55 \%$ reduction in risk of future CHD events compared with $33 \%$ in non-diabetic patients [105]. The evidence is now available for a far more aggressive approach to treating dyslipidaemia in diabetic patients with the chance to considerably reduce CHD morbidity and mortality $[105,106]$. The results of the $4 \mathrm{~S}$ and CARE studies have validated the vast epidemiological endeavour to define modifiable risk determinants of CVD in people with diabetes.

This new knowledge [105, 106], and the UKPDS [101], provide an important lesson for all those responsible for the clinical management of people with Type II diabetes. The message is now very clear that management should focus not only on tight blood glucose control but also on strategies for reduction of the other important CVD risk factors such as hypertension, dyslipidaemia and obesity. Furthermore, epidemiological studies have shown that the presence of microalbuminuria in patients with Type II diabetes is a harbinger of high CVD risk and mortality [107] and even if this is not an aetiological association, it certainly is a powerful marker of risk.

The other features of the metabolic syndrome can be present 5 to 8 years (Table 7) before diagnosis of Type II diabetes. This is shown well in the epidemiological studies in Mexican Americans [108], Rancho
Table 7. Mauritius age-adjusted baseline cardiovascular disease (CVD) characteristics measured in 1987 in men with normal glucose tolerance developing Type II diabetes in 1992

\begin{tabular}{|c|c|c|}
\hline \multirow{2}{*}{$\begin{array}{l}\text { CVD Risk factor } \\
\text { (baseline 1987) }\end{array}$} & \multicolumn{2}{|c|}{1992 Status } \\
\hline & $\begin{array}{l}\text { Normal } \\
\text { glucose } \\
\text { tolerance }\end{array}$ & $\begin{array}{l}\text { Converted } \\
\text { to diabetes }\end{array}$ \\
\hline Body mass index $\left(\mathrm{kg} / \mathrm{m}^{2}\right)$ & 22.4 & $24.3^{\mathrm{b}}$ \\
\hline Waist : hip ratio & 0.88 & $0.91^{\mathrm{b}}$ \\
\hline Diastolic blood pressure $(\mathrm{mm} \mathrm{Hg})$ & 78.3 & $82.0^{\mathrm{a}}$ \\
\hline Fasting insulin (mU/l) & 4.1 & $6.5^{\mathrm{b}}$ \\
\hline 2 -h insulin $(\mathrm{ng} / \mathrm{ml})$ & 20.2 & $35.6^{\mathrm{b}}$ \\
\hline 2-h plasma glucose $(\mathrm{mmol} / \mathrm{l})$ & 5.2 & $6.3^{\mathrm{b}}$ \\
\hline Fasting plasma triglycerides $(\mathrm{mmol} / \mathrm{l})$ & 1.3 & $1.9^{\mathrm{b}}$ \\
\hline
\end{tabular}

${ }^{\mathrm{a}} p<0.05^{\mathrm{b}} p<0.001$

Bernardo [109] and Mauritius [20, 110]. Thus, the risk and the actual development of CVD may commence many years before glucose intolerance manifests. Haffner and his co-workers have posed the very relevant question: "Does the clock for coronary heart disease start ticking before the onset of clinical diabetes"? [108] These data assume great importance in relation to our understanding of the aetiology of Type II diabetes, the associated CVD risk and the potential to prevent CVD and its morbidity and mortality in people with glucose intolerance.

Therefore and paradoxically, the prevention of clinical CVD in people with Type II diabetes should commence well before their diabetes is diagnosed. The diagnosis of the metabolic syndrome without Type II diabetes provides a group at very high risk of future Type II diabetes [110]. Aggressive early management of the syndrome (focussing not only on the pharmacological treatment of dyslipidaemia and hypertension, but also on weight reduction, diet and exercise) may have a considerable impact on both the prevention of Type II diabetes and CVD mortality.

\section{Hyperinsulinaemia, insulin resistance and the metabolic syndrome - or is it hyperleptinaemia?}

In 1994, there was an immensely important discovery in obese $(o b / o b)$ mice that heralded a new era in obesity research. It held out the promise for a new avenue of therapy for obesity and for possibly related disorders such as insulin resistance and Type II diabetes. Quite unexpected was the report from Friedman's laboratory of the cloning of the mouse obese $(o b)$ gene and its human homologue [111]. Within months it was reported that injections of the $o b$ protein (leptin) expressed by the $o b$ gene resulted in diminished food intake, increased energy expenditure and sudden weight reduction in $o b / o b$ mice [112]. After 2 weeks of treatment, there was a considerable re- 
duction of body fat and amelioration of hyperglycaemia and hyperinsulinaemia. The $o b / o b$ mice are hypoleptinaemic [112] as opposed to the majority of obese humans in whom leptin is high [113,114]. Rare instances of obesity in humans associated with hypoleptinaemia and a mutation of the $o b$ gene have, however, been reported [115]. Leptin is now recognised as having numerous metabolic effects [116].

Leptin and the thrifty gene. The discovery of leptin [111] and its diverse role not only in appetite regulation but also in reproduction [115] brings a new perspective to the debate about the "thrifty genotype" hypothesis [117]. This hypothesis is applied to populations that appear to have genes that favour increased fat storage in times of feast but produce obesity, hyperinsulinaemia and Type II diabetes in the transition to a modern life-style characterized by sedentary activity and relative overnutrition [20]. There also may be reproductive advantages conveyed by this genotype [118]. Leptin appears to have an important role in the control of body mass, by regulating appetite and energy expenditure, the adaptation to starvation, and the initiation of puberty $[115,116]$. Given the context of the thrifty gene, it is possible that leptin may have had an important role in adaptation to the feast and famine scenario [119].

Although it might appear to be outside the brief of this review, some speculation on this issue seems warranted as there is a clear need for more detailed epidemiological studies. The genetic basis for obesity in $o b / o b$ mice is an $o b$ gene mutation [111]. This mutation is extremely rare in humans [115] and obesity is almost always associated with hyperleptinaemia $[114,116]$. The $o b$ gene is overexpressed in adipose tissue of most animal models of obesity and in obese humans $[116,120]$. Resistance to leptin, due to a mutation/s of the leptin or leptin receptor gene or of leptin signalling, could be the phenotypic expression of Neel's thrifty gene $[117,119]$. It is possible that the development of leptin resistance is a survival advantage for people exposed to a varying food supply. When food is plentiful, large quantities could be consumed to store the excess as fat for use in times of famine. The ability to develop leptin resistance would be a survival advantage by permitting consumption of food without the usual homeostatic appetite-suppressing leptin signal and thus allowing storage of excess energy as fat. In an environment of plentiful food, the development of leptin resistance would result in hyperphagia, hyperinsulinaemia and obesity, then Type II diabetes and other components of the metabolic syndrome.

Obesity is epidemic in many developing populations, particularly the Pacific Islanders associated with modernisation [121]. The above scenario is consistent with the natural course of obesity and Type II diabetes in Pacific islanders $[15,121]$ whereby a me-

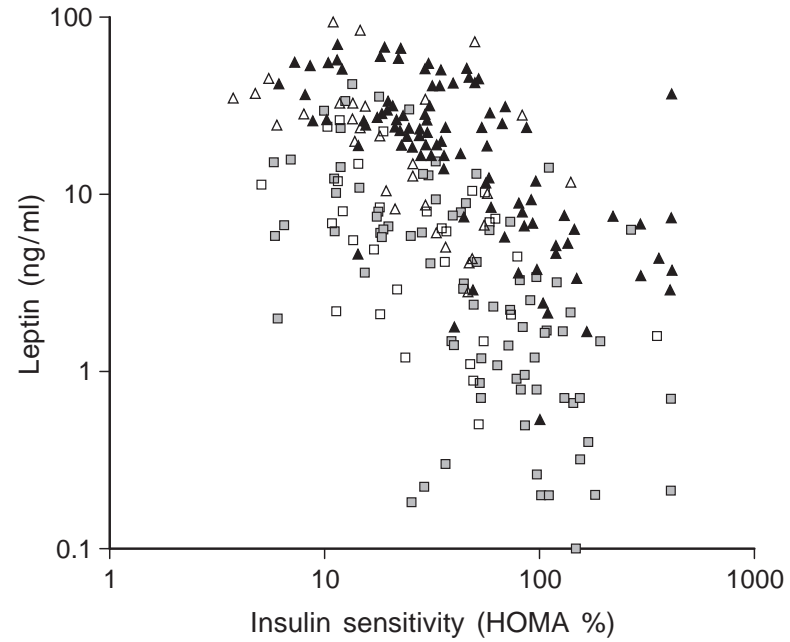

Fig. 6. Association of serum leptin with insulin sensitivity (HOMA) in $\square$ non-diabetic men $(r=0.64, p<0.001)$, $\square$ men with diabetes $(r=0.54, p<0.03)$ and $\boldsymbol{\Delta}$ non-diabetic women $(r=0.67, p<0.001)$ or $\triangle$ women with diabetes $(r=0.58$, $p<0.001$ ) from Western Samoa (From ref. 126)

tabolism suited to rapid weight gain through hyperleptinaemia, then hyperinsulinaemia and selective tissue insulin resistance would have been a survival factor.

Several other possible scenarios exist for the role of leptin in both the pathogenesis of Type II diabetes and insulin resistance. These require further attention in combined epidemiological and basic research. Firstly, that a hypothalamic-mediated resistance to leptin causes a rise in leptin and initiates hyperinsulinaemia/insulin resistance. Hyperinsulinaemia leads to increased body fat, dyslipidaemia due to lipogenesis and selective insulin resistance in muscle. The increased adipose mass produces more leptin but as a result of down regulation or insensitivity of the hypothalamic leptin receptor, feedback regulation of appetite and energy balance break down. Hyperinsulinaemia is then sustained by unregulated and continued feeding and the "vicious" cycle of hyperinsulinaemia, more fat and then more leptin and resistance to its action is perpetuated.

Another possible scenario is that insulin resistance may cause increased body fat, particularly centrally. More leptin is secreted from the expanding adipose tissue, the leptin receptor downregulates and appetite control is lost and a similar vicious cycle is perpetuated. Our group and others have now reported an association of hyperleptinaemia with obesity in human epidemiological studies [113, 114, 119, 122]. Blood leptin concentrations are four to five times higher in obese than non-obese people and there is an inverse relation between leptin and insulin sensitivity (Fig.6). These results suggest that obesity in humans represents a state of leptin resistance [116, 119]. 
Leptin and insulin resistance. Another major issue for debate and of controversy in the last decade has been the relation between insulin resistance and other CVD risk factors, including glucose intolerance [5]. Hyperinsulinaemia has been found to predict both Type II diabetes and coronary artery disease in a number of epidemiological studies [20, 84, 110, 123]. It has been suggested that insulin resistance or hyperinsulinaemia or both may be the common aetiological factor/s for the components of the metabolic syndrome, although there appears to be considerable heterogeneity in this relation between populations $[5,124]$.

More recently, we suggested that hyperleptinaemia rather than hyperinsulinaemia may be the missing link in the metabolic syndrome [119]. Hyperleptinaemia has been found to be associated with insulin resistance independent of body mass in clinical studies with the euglycaemic insulin clamp technique [125]. We have confirmed this association with insulin resistance on an epidemiological basis in Polynesians from Western Samoa [114] and in Mauritius [126] and have found evidence that hyperleptinaemia/leptin resistance is an important new component of the metabolic syndrome [119]. Another more recent study from the United Kingdom supports this contention [127]. The debate is still wide open with some in vitro $[116,120,128]$ and in vivo [116, 120, 129-131] studies having shown disparate and sometimes opposite effects of leptin on glucose uptake and insulin action. Additionally, on a crosssectional basis, glucose intolerance is not associated with any changes in leptin concentrations compared with normal subjects [114]. As the majority of human studies have been carried out on small groups of patients, their representativity is still open to question. Certainly, epidemiological data [114, 119, 126, 127, 132-133] and certain in vivo studies in Psammomys obesus, an excellent animal model of obesity, insulin and leptin resistance and Type II diabetes [134-136] keeps alive the possibility of an important role for leptin in either causing insulin resistance or modulating insulin sensitivity. Further longitudinal studies examining the effect of leptin on insulin resistance will clarify the direction of association between the two.

There is evidence to add hyperleptinaemia to the risk factor cluster that constitutes the metabolic syndrome [119] (Table 8). Hyperleptinaemia is just one of a number of extra components that have been proposed for the syndrome. To date, there has been no internationally agreed definition for the metabolic syndrome or criteria for the major components. The recent report of the WHO consultation [36] on the classification and criteria of diabetes has proposed a working definition and suggested key components and criteria (Table 9). This at least will provide a basis for developing an internationally acceptable defi-
Table 8. The cardiovascular disease risk factor cluster components of a revised metabolic syndrome which now includes hyperlipidaemia and leptin resistance

- Glucose intolerance

- Hyperinsulinaemia

- Insulin resistance

- Hypertension

- Upper body obesity

- Increased VLDL triglycerides

- Decreased HDL cholesterol

- Hyperleptinaemia

- Leptin resistance

- Microalbuminuria

- Increased PAI-1

PAI-1, plasminogen activator inhibitor-1

Table 9. The criteria for the various components ${ }^{\mathrm{a}}$ of the metabolic syndrome as proposed by the WHO Consultation on Definition, Diagnosis and Classification of Diabetes Mellitus and its Complications (from ref. 43)

1. Impaired glucose regulation or diabetes

2. Insulin resistance (under hyperinsulinaemic euglycaemic conditions, glucose uptake below lowest quartile for background population under investigation)

3. Raised arterial pressure $\geq 160 / 90 \mathrm{~mm} \mathrm{Hg}$

4. Raised plasma triglycerides ( $\geq 1.7 \mathrm{mmol} / \mathrm{l} ; 150 \mathrm{mg} / \mathrm{dl})$ and/or HDL cholesterol $(<0.9 \mathrm{mmol} / 1,35 \mathrm{mg} / \mathrm{dl} \mathrm{men} ;<1.0 \mathrm{mmol} / \mathrm{l}$, $39 \mathrm{mg} / \mathrm{dl}$ women)

5. Central obesity (males: waist : hip ratio $>0.90$; females: waist : hip ratio $>0.85$ ) and/or BMI $>30 \mathrm{~kg} / \mathrm{m}^{2}$

6. Microalbuminuria (urinary albumin excretion rate $\geq 20 \mu \mathrm{g}$ min or albumin: creatinine ratio $\geq 20 \mathrm{mg} / \mathrm{g}$ )

a Several other components of the metabolic syndrome have been described (e.g. hyperuricaemia and raised PAI-1). They are not necessary for the recognition of the condition

nition that will allow standardization for classification, epidemiological studies and clinical research.

Thrifty genotype or thrifty phenotype? Low birth weight has been proposed as a new and important risk factor for Type II diabetes [137]. Studies in the United Kingdom have shown an inverse relation between birth weight and glucose tolerance in adult life. This concept of a "thrifty phenotype" has created considerable interest but does it hold up against available evidence? Hales and Barker suggested that low birth weight, a reflection of nutritional deficiency in utero, is related to the later development of glucose intolerance, both IGT and Type II diabetes, independent of current BMI and social class [138]. Their interpretation of these findings was that impaired function of the endocrine pancreas and other tissues (involved in insulin sensitivity) results from the longterm effects of the nutritional deprivation affecting fetal and infant growth. They suggested this scenario applies in high-prevalence communities such as the Nauruans. They then proposed the thrifty phenotype hypothesis claiming that Type II diabetes is mainly 
the result of environmental determinants and that genetic factors have minimal or no role [137]. A number of studies, including other longitudinal studies have confirmed the epidemiological association [139-141] but there are also those which question it [142]. There now appears to be only minor controversy about the epidemiological association between low birth weight and glucose intolerance. Can it, however, really be claimed [137], that there is no genetic component in Type II diabetes and that all is due to environment? This seems to be the main area of controversy!

Some workers in the field [143-145] have questioned their interpretation pointing out that, paradoxically, their data could be consistent with the thrifty genotype hypothesis. It is possible that those fetuses carrying a "survival of the fittest" gene in an environment of intrauterine malnutrition are more likely to survive [143]. This possibility is, in fact, consistent with the thrifty genotype. It is based on the proposal that the United Kingdom study [138] is of necessity limited to survivors (small infants genetically predisposed to insulin resistance and Type II diabetes) and the thrifty phenotype hypothesis takes no account of the high mortality associated with a low birth weight. In addition, less than $10 \%$ of adults with glucose intolerance had a low birth weight [137, 144]. Thus, even if the relation is ultimately shown to be causal, low birth weight explains only a small proportion of diabetes and does not exclude the importance of other hypotheses (such as the thrifty genotype).

These issues and a number of others challenging the thrifty phenotype concept have been reviewed in detail recently [146] and it was pointed out that claiming causal inference in this association must be seriously challenged. Programming studies are unique in that potential causes are temporally separated from effects by a span of some five decades. The authors of the review [146] listed various direct and indirect pieces of evidence that suggest the reported association of low birth weight and subsequent Type II diabetes may be biased rather than causal. They state: “. ...selection bias, failure to define, measure, and adequately control for the confounding health consequences of social deprivation and inconsistencies in the hypotheses tested and in methods of data analysis and reporting are among the factors that weigh against a causal explanation for the associations observed" [146].

Added weight to their view comes with a recent study [147] which reports that size at birth is influenced by common genetic variation in insulin gene (INS) expression or in a neighbouring gene, such as $I G F 2$, regulated by the variable number of tandem repeats $(V N T R)$. The authors suggest that INS VNTR class III/III is a candidate gene for a thrifty genotype which leads to enhanced growth in utero and could bestow a survival advantage during human history in times of low food availability. This finding adds a new dimension to this controversy and provides a basis for a new approach to determine the genetic contribution.

\section{Primary prevention of Type II diabetes}

The thrifty gene [117] provides a basis for a better understanding of strategies to prevent Type II diabetes. A trait previously advantageous and which permitted survival during famine, i.e. favoured conservation and storage of energy as fat, now leads to insulin resistance, Type II diabetes and obesity in times of affluence [118]. A return to the hunter-gatherer scenario, healthy nutrition along with exercise, resulting in reduced energy intake and increased energy expenditure with weight reduction provides the logical means of prevention. This is supported by the only major population-based intervention yet reported, the DaQing study in China [148]. Here, the incidence of IGT converting to Type II diabetes was reduced by a third in the intervention compared with the control group. Given the projected epidemic of diabetes in China [5], such a potentially cost-effective intervention is of great importance. We have also recently shown that a similar community-based lifestyle approach in Mauritius could reduce some of the key risk factors for Type II diabetes and CVD such as eating behaviour, sedentariness, serum lipids and cigarette smoking $[149,150]$.

The Mauritius study [22] has provided important epidemiological and public health data for tackling prevention. It shows that health, behaviour and riskfactor status can be modified, albeit sometimes through legislative change $[149,150]$ and that an integrated approach to Type II diabetes and other non-communicable disease prevention and control [6] is feasible. The Mauritius study supported the evidence that for CVD the clock starts ticking before the diagnosis of diabetes [110]. By the time of diagnosis of diabetes, it may already be too late for interventions to have their full impact on cardiovascular disease. This direction could have only come through well planned longitudinal epidemiological studies as in Bedford [12], the Pima Indians [13] Mexican Americans [108], Rancho Bernado [109] and Mauritius [22].

\section{Epidemiology and society}

The study of epidemiology involves much more than number counting. Risk determinants for non-communicable diseases such as Type II diabetes go to the very core of the social, cultural, economic and behavioural factors in a society. In tackling Type II diabetes, the fight is not just against an individual disease but against the tide of modernization and glo- 
balization that has seen the underprivileged nations and people going backwards while the developed nations enjoy unprecedented economic growth. There is an urgent need to address the socio-economic, behavioural, nutritional and public health issues that have led to the Type II diabetes, obesity and CVD epidemic [5,110]. This is yet another example where epidemiological studies of diabetes and its public health significance have triggered, and will continue to stimulate, research into how to prevent diabetes and reduce the burden of its devastating complications.

Acknowledgements. My research has been generously supported by the National Institute of Diabetes and Kidney Diseases Grant DK-25446. I acknowledge the considerable contributions of my colleagues and collaborators G. Dowse, M. deCourten, V. Collins, G. Collier, I. Mackay, M. Rowley, T. Tuomi, A. Hodge, A. Humphrey, J. Shaw, D. McCarty, P. Bennett, H. King, R. Turner, W. Knowles, K. G. G. M. Alberti, J. Tuomilehto. I also wish to thank Drs J. Shaw and M. de Courten for their helpful comments on the manuscript and S. Fournel for its preparation.

\section{References}

1. Proceedings of the Kroc Foundation International Conference on Epidemiology of Diabetes and its Macrovascular Complications (1979) Diabetes Care 2: 63-226

2. National Diabetes Data Group (1979) Classification and diagnosis of diabetes mellitus and other categories of glucose intolerance. Diabetes 28: 1039-1057

3. World Health Organization Expert Committee on Diabetes Mellitus (1980) Second Report. Technical Report Series 646, WHO, Geneva

4. Major RM (1954) A history of medicine. Blackwell, Oxford, $\mathrm{p} 67$

5. Zimmet PZ (1995) The pathogenesis and prevention of diabetes in adults. Diabetes Care 18: 1050-1064

6. World Health Organization Study Group on Prevention of Diabetes Mellitus (1994) Technical Report Series No 844, WHO Geneva

7. World Bank (1993) World Development Report 1993: Investing in Health. World Development Indicators. Oxford University Press, Oxford

8. National Diabetes Data Group (1995) Diabetes in America. US Dept. of Health and Human Services, PHS

9. Colaguiri S, Colaguiri R, Ward J (1998) National Diabetes Strategy and Implementation Plan. Diabetes Australia, Canberra

10. West KM (1978) Epidemiology of diabetes and its vascular lesions. Elsevier, New York

11. The World Health Organization Multinational Study of Vascular Disease in Diabetics. (1985) Prevalence of small vessel and large vessel disease in diabetic patients from 14 centres. Diabetologia 28 [Suppl]: 615-640

12. Sharp CL, Butterfield WJH, Keen H (1964) Diabetes survey in Bedford, 1962. Proc R Soc Med 57: 193-204

13. Bennett PH, Burch TA, Miller M (1971) Diabetes mellitus in American (Pima) Indians. Lancet ii: 125-128

14. Zimmet P, Taft P, Guinea A, Guthrie W, Thoma K (1977) The high prevalence of diabetes mellitus on a Central $\mathrm{Pa}-$ cific island. Diabetologia 13: 111-115
15. Zimmet P, Dowse G, Finch C, Serjeantson S, King H (1990) The epidemiology and natural history of NIDDM - lessons from the South Pacific. Diabetes Metab Rev 6: 91-124

16. King H, Rewers M (1993) World Health Organization Ad Hoc Diabetes Reporting Group. Global estimates for prevalence of diabetes mellitus and impaired glucose tolerance in adults. Diabetes Care 16: 157-177

17. O'Dea K (1991) Westernisation, insulin resistance and diabetes in Australian Aborigines. Med J Aust 155: 258-264

18. Zimmet P (1992) Challenges in diabetes epidemiology from West to the Rest. Diabetes Care 15: 232-252

19. McCarty D, Amos A, Zimmet P (1997) The rising global burden of diabetes and its complications: estimates and projections to the year 2010. Diabet Med 14 [suppl 5]: S1-S85

20. de Courten M, Bennett PH, Tuomilehto J, Zimmet $\mathrm{P}$ (1997) Epidemiology of NIDDM in Non-Europids. In: Alberti KGMM, Zimmet P, DeFronzo RA (eds) International textbook of diabetes mellitus. 2nd edn. Wiley, Chichester, pp 143-70

21. Songer TJ, Zimmet P (1995) Epidemiology of Type 2 diabetes: an international perspective. PharmacoEconomics 8 [suppl 1]: 1-11

22. Dowse GK, Gareeboo H, Zimmet PZ (1990) High prevalence of NIDDM and impaired glucose intolerance in Indian, Creole and Chinese Mauritians. Diabetes 39: 390-396

23. Tan CE, Emmanuel SC, Tan B-Y, Jacob E (1999) Prevalence of diabetes and ethnic differences in cardiovascular risk factors. The 1992 Singapore National Health Survey. Diabetes Care 22: 241-247

24. Chou P, Chen H, Hsiao K (1992) Community-based epidemiological study on diabetes in $\mathrm{Pu}-\mathrm{Li}$, Taiwan. Diabetes Care 15: 81-89

25. Shanghai Diabetes Research Cooperative Group (1980) Diabetes Mellitus Survey in Shanghai. Chin Med J 93: 663-672

26. Pan X-R, Yang W-Y, Li G-W, Liu J, The National Diabetes Prevention and Control Cooperative Group (1997) Prevalence of diabetes and its risk factors in China, 1994. Diabetes Care 20: 1664-1669

27. Pan CY, Lu JM, Tian H et al. (1996) Study of the prevalence of diabetes mellitus in the Shougang Corporation in Beijing. Diabet Med 13: 663-668

28. Himsworth HP (1936) Diabetes mellitus: its differentiation into insulin-sensitive and insulin insensitive types. Lancet i: $117-120$

29. McCarthy MI, Froguel P, Hitman GA (1994) The genetics of non-insulin-dependent diabetes mellitus: tools and aims. Diabetologia 37: 959-968

30. Groop L (1997) The molecular genetics of non-insulin dependent diabetes mellitus. J Intern Med 241: 95-100

31. World Health Organization Study Group on Diabetes Mellitus (1985) Technical Report Series No 727, WHO Geneva

32. Alberti KGMM, Zimmet PZ (1998) New diagnostic criteria and classification of diabetes - again? Diabet Med 15: 535-536

33. Zimmet P, Turner R, McCarty D, Rowley M, Mackay IR (1999) Crucial points at diagnosis - NIDDM or slow IDDM Diabetes Care 22: in press

34. Rosenbloom AL, Joe JR, Young RS, Winter WE (1999) Emerging epidemic of Type 2 diabetes in youth. Diabetes Care 22: 345-354

35. The Expert Committee on the Diagnosis and Classification of Diabetes Mellitus (1997) Report of the Expert 
Committee on the Diagnosis and Classification of Diabetes Mellitus. Diabetes Care 20: 1183-1197

36. Alberti KGMM, Zimmet PZ for the World Health Organization Consultation (1998) Definition, diagnosis and classification of diabetes mellitus and its complications. Part 1: Diagnosis and classification of diabetes mellitus. Provisional Report of a WHO Consultation. Diabetic Med 15: 539-553

37. Kuzuya T, Matsuda A (1997) Classification of diabetes on the basis of etiologies versus degree of insulin deficiency. Diabetes Care 20: 219-220

38. DeFronzo RA, Bonadonna RC, Ferrannini E (1997) Pathogenesis of NIDDM. In: Alberti KGMM, Zimmet P, DeFronzo RA (eds) International textbook of diabetes mellitus. 2nd edn. Wiley, Chichester, pp 635-712

39. Hattersley AT (1998) Maturity-onset diabetes of the young: clinical heterogeneity explained by genetic heterogeneity. Diabet Med 15: 15-24

40. Tuomi T, Groop LC, Zimmet PZ, Rowley MJ, Knowles W, Mackay IR (1993) Antibodies to glutamic acid decarboxylase reveal latent autoimmune diabetes mellitus in adults with a non-insulin-dependent onset of disease. Diabetes 42: 358-362

41. Mølbak AG, Christau B, Marner B, Borch-Johnsen K, Nerup J (1994) Incidence of insulin-dependent diabetes mellitus in age groups over 30 years in Denmark. Diabet Med 11: 650-655

42. Zimmet PZ, Tuomi T, Mackay R et al. (1994) Latent autoimmune diabetes mellitus in adults (LADA): the role of antibodies to glutamic acid decarboxylase in diagnosis and prediction of insulin dependency. Diabet Med 11: 299-303

43. Tuomilehto J, Zimmet P, Mackay IR et al. (1994) Antibodies to glutamic acid decarboxylase as predictors of insulin-dependent diabetes mellitus before the clinical onset of the disease. Lancet 343: 1383-1385

44. UK Prospective Diabetes Study (UKPDS) (1991) VIII Study design, progress and performance. Diabetologia 34: 877-890

45. Gleichmann H, Zörcher B, Greulich B et al. (1984) Correlation of islet cell antibodies and HLA-DR phenotypes with diabetes mellitus in adults. Diabetologia 27: 90-92

46. Groop LC, Bottazzo GF, Doniach D (1986) Islet cell antibodies identify latent type I diabetes in patients aged 35-75 years at diagnosis. Diabetes 35: 237-241

47. Willis JA, Scott RS, Brown LJ et al. (1996) Islet cell antibodies and antibodies against glutamic acid decarboxylase in newly diagnosed adult-onset diabetes mellitus. Diabetes Res Clin Pract 33: 89-97

48. Zimmet PZ, Shaten BJ, Kuller LH, Rowley MJ, Knowles WJ, Mackay IR (1994) Antibodies to glutamic acid decarboxylase and diabetes mellitus in the multiple risk factor intervention trial. Am J Epidemiol 140: 683-690

49. Hagopian WA, Karlsen AE, Gottsater A et al. (1993) Quantitative assay using recombinant human islet glutamic acid decarboxylase (GAD65) shows that $65 \mathrm{~K}$ autoantibody positivity at onset predicts diabetes type. J Clin Invest 91: 368-374

50. Niskanen LN, Tuomi T, Karjalainen J, Groop LC, Uusitupa MIJ (1995) GAD antibodies in NIDDM. Ten-year follow-up from the diagnosis. Diabetes Care 18: 1557-1565

51. Wroblewski M, Gottsater A, Lindgarde F, Fernlund P, Sundkvist G (1998) Gender, autoantibodies, and obesity in newly diagnosed diabetic patients aged $40-75$ years. Diabetes Care 21: 250-255

52. Turner R, Stratton I, Manley S et al. (1997) UKPDS2: Autoantibodies to islet-cell cytoplasm and glutamic acid de- carboxylase for prediction of insulin requirement in type 2 diabetes. Lancet 350: 1288-1293

53. Beischer NA, Wein P, Sheedy MT, Mackay IR, Rowley MJ, Zimmet P (1995) Prevalence of antibodies to glutamic acid decarboxylase in women who have had gestational diabetes. Am J Obstet Gynecol 173: 1563-1569

54. Füchtenbusch M, Ferber K, Standl E, Ziegler AG, and participating centers (1997) Prediction of type 1 diabetes postpartum in patients with gestational diabetes mellitus by combined islet cell autoantibody screening. A Prospective Multicenter Study. Diabetes 46: 1459-1467

55. Horton V, Stratton I, Bottazzo GF et al. for the UK Prospective Diabetes Study (UKPDS) Group (1999) Genetic heterogeneity of autoimmune diabetes: age of presentation in adults is influenced by HLA DRB1 and DQB1 genotypes. Diabetologia 42: 608-616

56. King H, Senator G, Zimmet P, Harris A (1986) The Tasmanian insulin-treated diabetes register. Inception and progress in the first 12 months. Med J Aust 144: 414-416

57. Humphrey ARG, McCarty DJ, Mackay IR, Rowley MJ, Dwyer T, Zimmet P (1998) Autoantibodies to glutamic acid decarboxylase and phenotypic features associated with early insulin treatment in individuals with adult-onset diabetes mellitus. Diabet Med 15: 113-119

58. Zimmet PZ, Elliott RB, Mackay IR et al. (1994) Autoantibodies to glutamic acid decarboxylase and insulin in presymptomatic insulin-dependent diabetes mellitus: frequency and segregation by age and gender. Diabet Med 11: 866-871

59. Feeney SJ, Myers MA, Rowley MJ (1997) Evaluation of ICA512 autoantibodies in combination with other islet cell autoantibodies at the onset of insulin dependent diabetes mellitus. Diabetes Care 20: 1403-1407

60. Whittingham S, Byron S, Tuomilehto J et al. (1997) Autoantibodies associated with presymptomatic insulin-dependent diabetes mellitus in women. Diabet Med 14: 678-685

61. Eastman R, Javitt J, Herman W, Dasbach E, Harris M (1996) Prevention strategies for non-insulin-dependent diabetes mellitus: an economic perspective. In: Le-Roith D, Taylor S, Olefsky J (eds) Diabetes mellitus: a fundamental and clinical text. Lippincott-Raven Publishers, New York, pp 621-630

62. Vionnet N, Stoffel M, Takeda J et al. (1992) Nonsense mutation in the glucokinase gene causes early-onset non-insulin-dependent diabetes. Nature 356: 721-722

63. Bell GI, Xiang K-S, Newman MV et al. (1991) Gene for noninsulin-dependent diabetes mellitus (maturity-onset diabetes of the young subtype) is linked to DNA polymorphism on human chromosome 20q. Proc Natl Acad Sci USA 88: 1484-1488

64. Yamagata K, Oda N, Kaisaki PJ et al. (1996) Mutations in the hepatocyte nuclear factor-1 $\alpha$ gene in maturity-onset diabetes of the young (MODY 3). Nature 384: 455-458

65. Yamagata K, Furuta H, Oda N et al. (1996) Mutations in the hepatocyte nuclear factor- $4 \alpha$ gene in maturity-onset diabetes of the young (MODY 1). Nature 384: 458-460

66. Waterston R, Sulston JE (1998) The Human Genome Project: reaching the finishing line. Science 282: 53-54

67. de Courten M, Zimmet P (1997) Screening for non-insulin-dependent diabetes mellitus: where to draw the line. Diabet Med 14: 95-98

68. Zimmet P, de Courten M, Alberti KGMM (1998) New classification and criteria for diabetes - moving the goalposts closer. Editorial Med J Aust 168: 593-594

69. Rushforth NB, Bennett PH, Steinberg AG, Burch TA, Miller M (1971) Diabetes in the Pima Indians. Evidence 
of bimodality in glucose tolerance distributions. Diabetes 20: 756-765

70. Zimmet P, Whitehouse S, Alford F, Chisholm D (1978) The relationship of insulin response to a glucose stimulus over a wide range of glucose tolerance. Diabetologia 15: 23-27

71. Pettitt D, Knowler W, Lisse J, Bennett P (1980) Development of retinopathy and proteinuria in relation to plasma-glucose concentrations in Pima Indians. Lancet ii: 1050-1052

72. Finch CF, Zimmet PZ, Alberti KGMM (1990) Determining diabetes prevalence: a rational basis for the use of fasting plasma glucose concentrations? Diabet Med 7: 603-610

73. Charles MA, Fontbonne A, Thibult N, Warnet J-M, Rosselin GE, Eschwege E (1991) Risk factors for NIDDM in white population. Diabetes 40: 796-799

74. Charles MA, Balkau B (1996) Revision of diagnostic criteria for diabetes (Letter). Lancet 348: 1657-1658

75. De Vegt F, Dekker JM, Stehouwer CDA, Nijpels G, Bouter LM, Heine RJ (1998) The 1997 American Diabetes Association criteria versus the 1985 World Health Organization criteria for the diagnosis of abnormal glucose tolerance. Diabetes Care 21: 1686-1690

76. Unwin N, Alberti KGMM, Bhopal R, Harland J, Watson W, White M (1998) Comparison of the current WHO and new ADA criteria for the diagnosis of diabetes mellitus in three ethnic groups in the UK. Diabet Med 15: $554-557$

77. Gimeno SGA, Ferreira SRG, Franco LJ, Iunes M (1998) The Japanese-Brazilian Diabetes Study Group: comparison of glucose tolerance categories according to World Health Organization and American Diabetes Association diagnostic criteria in a population-based study in Brazil. Diabetes Care 21: 1889-1892

78. Shaw JE, Zimmet PZ, de Courten M et al. (1999) Impaired fasting glucose or imparied glucose tolerance: what best predicts future diabetes in Mauritius? Diabetes Care 22: 399-402

79. Dowse G, Zimmet P, Alberti K (1996) Screening for diabetes and glucose intolerance. In: Alberti K, Zimmet P, DeFronzo R, Keen HH (eds) International textbook of diabetes mellitus. 2nd edn, vol 2. Wiley, London, pp 1687-1707

80. Harris MI, Modan M (1994) Screening for NIDDM: why is there no national program? Diabetes Care 17: 440-444

81. American Diabetes Association (1998) Economic consequences of diabetes mellitus in the U.S. in 1997. Diabetes Care 21: 296-309

82. Harris MI (1993) Undiagnosed NIDDM; clinical and public health issues. Diabetes Care 16: 642-652

83. Harris MI, Klein R, Welborn TA, Knuiman MW (1992) Onset of NIDDM occurs at least 4-7 yr before clinical diagnosis. Diabetes Care 15: 815-819

84. Fontbonne A, Charles MA, Thibult N et al. (1991) Hyperinsulinaemia as a predictor of coronary heart disease mortality in a healthy population: the Paris Prospective Study, 15-year follow-up. Diabetologia 34: 356-361

85. Nathan DM (1993) Long term complications of diabetes mellitus. N Engl J Med 328: 1676-1685

86. Pettitt DJ, Knowler WC, Baird R, Bennett PH (1980) Gestational diabetes: infant and maternal complications of pregnancy in relation to third-trimester glucose tolerance in the Pima Indians. Diabetes Care 3: 458-464

87. Diabetic Control and Complications Trial Research Group (1993) The effect of intensive treatment on the development and progression of long-term complications in insulin-dependent diabetes mellitus. New Engl J Med 329: 977-986

88. Schatz D, Rogers DG, Brouhard BH (1996) Prevention of insulin-dependent diabetes mellitus: an overview of three trials. Cleve Clin J Med 63(5): 270-274

89. Gale EA (1996) Theory and practice of nicotinamide trials in pre-Type 1 diabetes. J Pediatr Endocrinol Metab 9: 375-379

90. Füchtenbusch M, Rabl W, Grassl B, Bachmann W, Standl E, Ziegler AG (1998) Delay of type 1 diabetes in high risk, first degree relatives by parenteral antigen administration: the Schwabing Insulin Prophylaxis Pilot Trial. Diabetologia 41: 536-541

91. Tisch R, Liblau RS, Yang X-D, Liblau P, McDevitt HO (1998) Induction of GAD65-specific regulatory T-cells inhibits ongoing autoimmune diabetes in nonobese diabetic mice. Diabetes 47: 894-899

92. Yamata H, Uchigata Y, Kawasaki E (1998) Onset age-dependent variations of three islet specific autoantibodies in Japanese IDDM patients. Diabetes Res Clin Pract 39: 211-217

93. Pozzilli P (1998) Prevention of insulin-dependent diabetes mellitus 1998. Diabetes Metabol Rev 14: 69-84

94. Skyler J, Marks J (1993) Immune Intervention In Type I Diabetes Mellitus. Diabetes Reviews 1 (1): 15-42

95. Tuomi T, Carlsson A, Haiyan L et al. (1999) Clinical and genetic characteristics of Type 2 diabetes with and without GAD antibodies. Diabetes 48: 150-157

96. Hamman RF (1997) Epidemiology of microvascular complications. In: Alberti KGMM, Zimmet P, DeFronzo RA (eds) International textbook of diabetes mellitus. 2nd edn. Wiley, Chichester, pp 1293-1319

97. Pirart J (1978) Diabetes mellitus and its degenerative complications: a prospective study of 4,400 patients observed 1947 and 1973. Diabetes Care 21: 168-88; 252-263

98. Reichard P, Nilsson BY, Rosenqvist U (1993) The effect of long-term intensified insulin treatment on the development of microvascular complications of diabetes mellitus. N Engl J Med 329: 304-309

99. Ohkubo Y, Kishikawa H, Araki E et al. (1995) Intensive insulin therapy prevents the progression of diabetic microvascular complications in Japanese patients with non-insulin-dependent diabetes mellitus: a randomized prospective 6-year study. Diabetes Res Clin Pract 28: 103-117

100. UK Prospective Diabetes Study Group (1998) Intensive blood glucose control with sulphonylureas or insulin compared with conventional treatment and risk of complications in patients with type 2 diabetes (UKPDS 33). Lancet 352: 837-853

101. UK Prospective Diabetes Study Group (1998) Tight blood pressure control and risk of macrovascular and microvascular complications in type 2 diabetes: UKPDS 38. BMJ 317: 703-713

102. Panzram G (1987) Mortality and survival in Type 2 (noninsulin-dependent) diabetes mellitus. Diabetologia 30: 123-131

103. Reaven GM (1988) Role of insulin resistance in human disease. Diabetes 37: 1595-1607

104. Zimmet P (1989) Non-insulin-dependent (Type 2) diabetes mellitus - does it really exist? Diabet Med 6: 728-735

105. Pyorälä K, Pedersen TR, Kjeksus J, Faergerman O, Olsson AG, Thorgeirsson G (1997) Cholesterol lowering with simvastatin improves prognosis of diabetic patients with coronary heart disease: a subgroup analysis of the Scandinavian Simvastatin Survival Study (4S). Diabetes Care 20: 614-620 
106. Sacks FM, Pfeffer MA, Moye LA et al. (1996) The effect of pravastatin on coronary events after myocardial infarction in patients with average cholesterol levels: Cholesterol and Recurrent Events Trial Investigators. N Engl J Med 335: 1001-1009

107. Niskanen LK, Penttilä I, Parviainen M, Uusitupa MIJ (1996) Evolution, risk factors, and prognostic implications of albuminuria in NIDDM. Diabetes Care 19: 486-493

108. Haffner SM, Stern MP, Hazuda HP, Mitchell BD, Patterson JK (1990) Cardiovascular risk factors in confirmed prediabetic individuals. Does the clock for coronary heart disease start ticking before the onset of clinical diabetes? JAMA 263: 2893-2898

109. McPhillips JB, Barrett-Conner E, Wingard DL (1990) Cardiovascular disease risk factors prior to the diagnosis of impaired glucose tolerance and non-insulin-dependent diabetes mellitus in a community of older adults. Am J Epidemiol 131: 443-453

110. Zimmet P, Alberti KGMM (1997) The changing face of macrovascular disease in non-insulin dependent diabetes mellitus in different cultures: an epidemic in progress. Lancet 350 [Suppl 1]: S1-S4

111. Zhang Y, Proenca R, Maffei M, Barone M, Leopold L, Friedman JM (1994) Positional cloning of the mouse obese gene and its human homologue. Nature 372: $425-432$

112. Halaas JL, Gajiwala KS, Maffei M et al. (1995) Weight-reducing effects of the plasma protein encoded by the obese gene. Science 269: 543-546

113. Considine RV, Sinha MK, Heiman ML et al. (1996) Serum immunoreactive-leptin concentrations in normal-weight and obese humans. N Engl J Med 334: 292-295

114. Zimmet P, Hodge A, Nicholson M et al. (1996) Serum leptin concentration, obesity, and insulin resistance in Western Samoans: cross sectional study. BMJ 313: 965-969

115. O'Rahilly S (1998) Life without leptin. Nature 392: 330-331

116. Auwerx J, Staels B (1998) Leptin. Lancet 351: 737-742

117. Neel JV (1962) Diabetes mellitus: a thrifty genotype rendered detrimental by 'progress'? Am J Hum Genet 14: 353-362

118. O'Dea K, Zimmet P (1993) Thrifty genotypes. In: Leslie RDG (ed) Causes of diabetes. Wiley, Chichester pp 269-290

119. de Courten M, Zimmet P, Hodge A et al. (1997) Hyperleptinaemia: the missing link in the Metabolic Syndrome? Diabet Med 14: 200-208

120. Tritos NA, Mantzoros CS (1997) Leptin: its role in obesity and beyond. Diabetologia 40: 1371-1379

121. Hodge AM, Dowse GK, Zimmet PZ, Collins VR (1995) Prevalence and secular trends in obesity in Pacific and Indian Ocean island populations. Obes Res 3 [Suppl. 2]: S77-S87

122. Hodge AM, de Courten MP, Zimmet PZ (1997) Leptin levels do not predict weight gain: a prospective Study. Diabetologia 40 [Suppl 1]: A262(abstract)

123. Pyörälä K, Savolainen E, Kaukola S, Haapakoski J (1982) High plasma insulin as coronary heart disease risk factor. In: Eschwege E (ed) Advances in diabetes epidemiology. INSERM Symposium No 22. Elsevier, Amsterdam, pp 143-148

124. Collins VR, Dowse GK, Finch CF, Zimmet PZ (1990) An inconsistent relationship between insulin and blood pressure in three Pacific island populations. J Clin Epidemiol 43: $1369-1378$
125. Segal KR, Landt M, Klein S (1996) Relationship between insulin sensitivity and plasma leptin concentration in lean and obese men. Diabetes 45: 988-991

126. Zimmet PZ, Collins VR, de Courten MP et al. (1998) Is there a relationship between leptin and insulin sensitivity independent of obesity? A population-based study in the Indian Ocean nation of Mauritius. Int J Obes Relat Metab Disord 21: 171-177

127. Leyva F, Godsland IF, Ghatei M et al. (1997) Hyperleptinemia as a component of a metabolic syndrome of cardiovascular risk. Arterioscler Thromb Vasc Biol 18: 928-933

128. Fürnsinn C, Brunmair B, Furtmüller R, Roden M, Englisch R, Waldhäusl W (1998) Failure of leptin to affect basal and insulin-stimulated glucose metabolism of rat skeletal muscle in vitro. Diabetologia 41: 524-529

129. Sivitz WI, Walsh SA, Morgan DA, Thomas MJ, Haynes WG (1997) Effects of leptin on insulin sensitivity in normal rats. Endocrinology 138: 3395-3401

130. Koyama K, Chen G, Wang M-Y et al. (1997) $\beta$-cell function in normal rats made chronically hyperleptinemic by adenovirus-leptin gene therapy. Diabetes 46: 1276-1279

131. Wang J, Liu R, Hawkins M, Barzllai N, Rossetti L (1998) A nutrient-sensing pathway regulates leptin gene expression in muscle and fat. Nature 393: 684-688

132. Haffner SM, Miettinen H, Mykkänen L, Karhapää P, Rainwater DL, Laakso M (1997) Leptin concentrations and insulin sensitivity in normoglycemic men. Int J Obes Relat Metab Disord 21: 393-399

133. Couillard C, Lamarche B, Mauriège P et al. (1998) Leptinemia is not a risk factor for ischemic heart disease in men. Diabetes Care 21: 782-786

134. Collier G, Walder K, Lewandowski P, Sanigorski A, Zimmet P (1997) Leptin and the development of obesity and diabetes in Psammomys obesus: Obes Res 5: 455-458

135. Walder K, Pilippis A, Clark S, Zimmet P, Collier G (1997) Leptin inhibits insulin binding in isolated rat adipocytes. $\mathrm{J}$ Endocrinol 155: R5-R7

136. Walder K, Willet M, Zimmet P, Collier GR (1997) Ob (obese) gene expression and leptin levels in Psammomys obesus. Biochimica et Biophysica Acta 1354: 272-278

137. Hales CN, Barker DJP (1992) Type 2 (non-insulin-dependent) diabetes mellitus: The thrifty phenotype hypothesis. Diabetologia 35: 595-601

138. Hales CN, Barker DJP, Clark PMS, Cox IJ, Fall C, Osmond C (1991) Fetal and infant growth and impaired glucose tolerance at age 64. BMJ 303: 1019-1022

139. Yajnik CS, Fall CHD, Vaidya U et al. (1995) Fetal growth and glucose and insulin metabolism in four-year-old Indian children. Diabet Med 12: 330-336

140. Ravelli ACJ, van der Meulen JHP, Michels RPJ et al. (1998) Glucose tolerance in adults after prenatal exposure to famine. Lancet 351: 173-177

141. Poulsen P, Vaag AA, Kyvik KO, Møller Jensen D, BeckNielsen H (1997) Low birth weight is associated with NIDDM in discordant monozygotic and dizygotic twin pairs. Diabetologia 40: 439-446

142. Stanner SA, Bulmer K, Andrès C et al. (1997) Does malnutrition in utero determine diabetes and coronary heart disease in adulthood? Results from the Leningrad siege study, a cross sectional study. BMJ 315: 1342-1349

143. Waldhäusl W, Fasching P (1993) Fetal growth and impaired glucose tolerance in men and women. Diabetologia 36: 973-974

144. McCance DR, Pettit DJ, Hanson RL, Jacobsson LTH, Knowler WC, Bennett PH (1994) Birth weight and noninsulin dependent diabetes: thrifty genotype, thrifty phe- 
notype, or surviving small baby genotype? BMJ 308: 942-945

145. Dowse GK, Zimmet PZ, Alberti KGMM (1993) Infant nutrition and subsequent risk of Type 2 (non-insulin-dependent) diabetes mellitus. Diabetologia 36: 267-268.

146. Joseph KS, Kramer MS (1996) Review of the evidence on fetal and early childhood antecedents of adult chronic disease. Epidemiol Rev 18: 158-174

147. Dungar DB, Ong KKL, Huxtable SJ et al. (1998) Association of the INS VNTR with size at birth. Nat Genet 19: 98-100

148. Pan X, Li G, Hu Y et al. (1997) Effect of diet and exercise in preventing NIDDM in people with impaired glucose tolerance: The Da Qing IGT and Diabetes Study. Diabetes Care 20: 537-544

149. Dowse GK, Gareeboo H, Alberti KGMM et al. (1995) Changes in population cholesterol concentrations and other cardiovascular risk factor levels after five years of the non-communicable disease intervention programme in Mauritius. BMJ 311: 1255-1259

150. Uusitalo U, Feskens EJM, Tuomilehto J et al. (1996) Fall in total cholesterol concentration over five years in association with changes in fatty acid composition of cooking oil in Mauritius: cross sectional survey. BMJ 313: 1044-1046 